Universidade de São Paulo

Instituto de Física de São Carlos

Departamento de Física e Informática

Grupo de Física Computacional e Instrumentação Aplicada

\author{
Rafael Giordano Viegas
}

\title{
Dissecação dinâmica de condutâncias iônicas em tempo real
}

São Carlos, SP

2011 



\section{Rafael Giordano Viegas}

\section{Dissecação dinâmica de condutâncias iônicas em tempo real}

Dissertação apresentada ao Programa de PósGraduação em Física do Instituto de Física de São Carlos da Universidade de São Paulo, para obtenção do título de Mestre em Ciências.

Área de concentração: Física Básica

Orientador: Prof.Dr. Reynaldo Daniel Pinto

Versão Corrigida

(versão original disponível na Unidade que aloja o Programa)

São Carlos, SP 


\section{AUTORIZO A REPRODUÇÃO E DIVULGAÇÃO TOTAL OU PARCIAL DESTE TRABALHO, POR QUALQUER MEIO CONVENCIONAL OU ELETRÔNICO, PARA FINS DE ESTUDO E PESQUISA, DESDE QUE CITADA A FONTE.}

Viegas, Rafael Giordano

Dissecação dinâmica de condutâncias iônicas em tempo real./ Rafael Giordano Viegas; orientador Reynaldo Daniel Pinto-versão corrigida-- São Carlos, 2011.

$71 \mathrm{p}$.

Dissertação (Mestrado - Programa de Pós-Graduação em Física - Área de concentração: Física Básica - Instituto de Física de São Carlos da Universidade de São Paulo.

1. Dynamic clamp. 2. Gânglio estomatogástrico. 3. Teoria da informação. 4. Codificação neural. 5. Modelagem realista de neurônios.

I. Título. 


\section{Agradecimentos}

Ao Reynaldo pela orientação e amizade.

À Ludmila B. Rodrigues pelas discussões, apoio e inestimável auxílio no laboratório e com os códigos.

Aos amigos e colegas de laboratório e do Dipteralab pelas discussões e convivência agradável: Carolina Menezes, Gisele Strieder, Jessica dos Santos, Rafael Tuma, Caroline Forlim, Ingrid Esteves, Nelson Fernandes, Paulo Matias, Lirio de Almeida e Ivanilda Zucolotto.

Aos professores que de alguma forma contribuíram para este trabalho, em especial, Roland Köberle e Leonardo Maia.

Ao Thiago Mosqueiro por ajudas em diversos momentos, em especial com o $\mathrm{AT}_{\mathrm{E} X d e s t a}$ dissertação.

À minha namorada, Suelen Amorim, pelo carinho, incentivo e compreensão durante esses anos.

À minha família pelo apoio irrestrito.

Aos meus amigos Rodrigo Euzébio, Pedro Tobita e Marcelo Boareto pelos momentos memoráveis e suporte.

Aos colegas do IFSC pela acolhimento, discussões e bons momentos durante as disciplinas.

Aos meus amigos do IBILCE/UNESP e de Bálsamo, que, embora a distância tenha nos afastado, foram importantes para que eu chegasse aqui.

Ao $\mathrm{CNPq}$ pelo suporte financeiro durante esta pesquisa.

A todos aqueles, enfim, que direta ou indiretamente contribuíram para a realização deste trabalho: muito obrigado! 



\section{Resumo}

VIEGAS, R. G. Dissecação dinâmica de condutâncias iônicas em tempo real. 2011. 71p. Dissertação (Mestrado) - Instituto de Física de São Carlos - Universidade de São Paulo, São Carlos, 2011.

Investigamos o papel de condutâncias iônicas lentas na transmissão/codificação de informação entre neurônios que disparam em rajadas ou bursts. Para isso, desenvolvemos um protocolo experimental no qual a interação em tempo real entre computador e neurônio biológico permite isolar o efeito da dinâmica de um determinado tipo de canal iônico e estudar sua influência nos mecanismos de codificação de informação. Os experimentos foram realizados com neurônios do gânglio estomatogástrico do siri azul, Callinectes sapidus, que não possuem condutâncias lentas capazes de fazê-los apresentar rajadas de disparos quando in vitro, condição na qual apresentam comportamento quiescente ou disparam tonicamente. Durante os experimentos, alteramos artificialmente o comportamento de um destes neurônios, conectando-o a um computador que introduz uma corrente capaz de fazê-lo apresentar rajadas. Essa corrente possui uma componente senoidal (vinda de um gerador de funções) e uma componente devido a uma condutância iônica lenta modelada matematicamente. A condutância lenta pode ser escolhida entre duas versões: uma em que a condutância é calculada em tempo real, a partir do valor instantâneo do potencial de membrana do neurônio biológico, e outra em que o valor da condutância é oriundo de uma série temporal previamente gravada. A fonte de informação utilizada nos experimentos é um neurônio artificial pré-sináptico, que possui uma distribuição de potenciais de ação (spikes) escolhida pelo experimentador, e é conectado ao neurônio biológico "modificado" através de um modelo de sinapse química inibidora. A quantidade de informação do neurônio artificial (variabilidade dos padrões de disparo) codificada pelo neurônio biológico é inferida calculando-se a informação mútua média entre eles para as duas versões da condutância lenta (dinâmica ou previamente gravada). Nossos experimentos reproduziram qualitativamente as observações feitas por nosso grupo no circuito pilórico intacto do siri, que possui neurônios conectados por mutua inibição que naturalmente apresentam bursts. Além disso, observamos que vários picos de informação mútua média, presentes quando a condutância é dinâmica, desaparecem quando esta é substituída pela série temporal previamente gravada da condutância. Assim, pudemos confirmar os resultados previamente obtidos com simulações computacionais em que foram utilizados apenas modelos matemáticos e na ausência de ruído e demonstramos que as condutâncias iônicas lentas constituem um mecanismo biofísico que permite a codificação de estímulos sinápticos em neurônios que apresentam rajadas.

Palavras-chave: Dynamic clamp. Gânglio estomatogástrico. Teoria da informação. Codificação neural. Modelagem realista de neurônios. 



\section{Abstract}

VIEGAS, R. G. Dynamic dissection of ionic conductances in real time. 2011. 71p. Dissertação (Mestrado) - Instituto de Física de São Carlos - Universidade de São Paulo, São Carlos, 2011.

We investigated the role of slow ionic conductances on information processing by bursting neurons. A real time experimental protocol was developed to allow interacting computer models and biological neurons to address the effect of dynamical details of a single type of ion channel in information coding mechanisms. We experimented on Callinectes sapidus (blue crab) stomatogastric ganglion neurons. Such neurons were chosen because they do not present the slow conductances that can led to bursting activity in vitro (in such conditions they can be found either in a quiescent or in a tonic firing state). The experiments consisted in artificially changing the behavior of one of these neurons by injecting a computer generated current to achieve bursting. Such current has a sinusoidal component (from a function generator) and a component due to mathematical model of a slow ionic conductance. The slow conductance was implemented in two versions: in one of them the instantaneous value of the conductance is computed in real time and according to the membrane potential of the biological neuron, in another version the value of the conductance simply comes from a time series previously stored in the computer. A pre-synaptic artificial neuron, with a spike distribution chosen by the experimenter, provided input for the biological neuron through an artificial chemical inhibitory synapse. The amount of information (variability of spike patterns from the artificial neuron) coded by the biological neuron was inferred by calculating the average mutual information along stimulus and response bursts for the two conditions of the slow conductance (dynamically calculated or from file previously stored). Our experiments reproduced the results found in intact pyloric central pattern generator bursting neurons connected by mutual inhibition. Moreover, we show that the average mutual information peaks, found when the conductance is dynamically calculated, disappear when we use the previously recorded time series of the conductance. Such results validate those only found previously in numerical simulations in the absence of noise and point the role of the slow ionic conductances in a biophysical mechanism that allow bursting motor neurons to encode in a nontrivial fashion the information they receive through a single synapse.

Keywords: Dynamic Clamp. Stomatogastric ganglion. Information theory. Neural coding. Realistic neural modeling. 



\section{Lista de Figuras}

Propriedades físicas dos canais iônicos . . . . . . . . . . . . . 24

IMM no $C P G$ pilórico e em simulações numéricas. . . . . . . . . . 42 


\section{Lista de Tabelas}

1 Parâmetros para sinapse química artificial . . . . . . . . . . . 68

2 Parâmetros utilizados para condutância lenta do tipo H. . . . . . . . . . . 69

3 Parâmetros utilizados na senóide. . . . . . . . . . . . . . . . . 69 



\section{Sumário}

1 Introdução

2 Metodologia 21

2.1 Os neurônios . . . . . . . . . . . . . . . . . . . . . . . . 21

2.1.1 O modelo de Hodgkin-Huxley . . . . . . . . . . . . . . . . . 24

2.2 O sistema nervoso estomatogástrico de crustáceos . . . . . . . . . . . . . 27

2.3 Dissecação do sistema estomatogástrico . . . . . . . . . . . . . . . 30

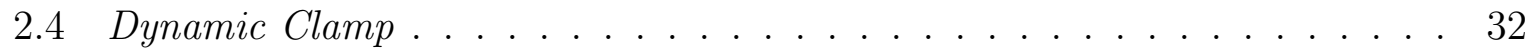

2.5 Teoria da informação . . . . . . . . . . . . . . . . . . . 34

3 Desenvolvimento $\quad 41$

3.1 Dissecação dinâmica em tempo real . . . . . . . . . . . . . . . . . . . 41

3.1.1 Dynamic Clamp adaptado . . . . . . . . . . . . . . 43

3.1 .2 Dissecação dinâmica no $C P G$ gástrico . . . . . . . . . . . . . 45

$\begin{array}{llr}4 & \text { Resultados } & 47\end{array}$

4.1 Introduzindo condutâncias lentas em células do $S T G \ldots$. . . . . . . 47

4.2 Análise de dados com Teoria da Informação . . . . . . . . . . . . . . . . . 49

$\begin{array}{lll}5 & \text { Conclusões } & 61\end{array}$

REFERÊNCIAS 
A.1 Condutância e sinapse artificiais . . . . . . . . . . . . . . . 67

A.2 Neurônio artificial . . . . . . . . . . . . . . . . . . . . . . . . . . 69 


\section{Introdução}

Desde os trabalhos seminais de Hodgkin e Huxley (1), o estudo das propriedades intrínsecas aos canais iônicos tornou-se a base de muitos trabalhos teóricos e experimentais. A razão disso é que os modelos baseados em condutâncias são capazes de reproduzir o comportamento das células nervosas em muitas situações observadas experimentalmente.

Entretanto, a variedade de canais iônicos e sua distribuição não homogênea ao longo da célula, faz com que os neurônios sejam sistemas não lineares altamente complexos. Neste sentido, entender o papel das propriedades intrínsecas à cada canal iônico no comportamento de células isoladas ou de redes ainda constitui um desafio (2).

Alguns neurônios possuem oscilações lentas do potencial de membrana, devido a canais iônicos seletivos a cálcio ou dependentes da concentração interna de cálcio, formando patamares de despolarização. Durante esta fase despolarizada, ocorre uma sequência de potenciais de ação, que são seguidos por períodos de hiperpolarização. Neste caso, dizemos que a célula dispara em rajadas de potenciais de ação ou bursts.

Embora estudos de modelos detalhados de células com atividade lenta tenham revelado muitos dos mecanismos responsáveis pela atividade em forma de bursts (3), pouco sabemos sobre suas propriedades de codificação de informação. No entanto, o fato destas células possuírem canais iônicos que operam em escalas temporais distintas, cria um cenário propício para que haja códigos simultâneos, envolvendo a distribuição de intervalos entre spikes (ISIs) e os intervalos entre bursts (4).

Um dos circuitos nervosos mais bem estudado é o gânglio estomatogástrico $(S T G)$ de crustáceos (5). Este gânglio possui duas pequenas redes neurais, com um total aproximado de 30 células, capazes de produzir padrões motores de maneira autônoma, influenciada por sinais sensoriais, mas sem necessitar destes para funcionar - o Gerador Central de Padrões $(C P G)$ pilórico e o gástrico. Os neurônios destes $C P G s$ podem ser identificados 
e permanecem produzindo os padrões motores por até 12 horas após terem sido retirados do animal. Desde sua descoberta na década de 70, os CPGs têm sido considerados paradigmas na análise de como uma dinâmica complexa emerge a partir das propriedades intrínsecas dos neurônios e das conexões sinápticas que estabelecem entre si (6).

No $C P G$ de crustáceos, a atividade em bursts é associada à contração muscular e atividade motora. Alguns estudos mostram que a contração muscular é insensível a pequenas alterações dos intervalos entre spikes durante um burst (7). A despeito da aparente falta de informação útil do ponto de vista motor, o padrão de disparos de spikes intra-burst $(I B S P)$ destes neurônios apresenta propriedades interessantes: estudos anteriores demostraram que neurônios do $C P G$ pilórico e de outros CPGs de invertebrados apresentam distribuições de IBSPs que são características de cada neurônio e que mudam de acordo com a conectividade da rede (8-9). Assim, além da informação motora expressa nos bursts, os neurônios dos CPGs tem o potencial de expressar outros tipos de informação, alterando seus IBSPs (4) .

Motivado por esses fatos, nosso grupo desenvolveu um protocolo para analisar, através de técnicas de teoria da informação, o processamento e transmissão de informação entre células do $C P G$ pilórico (10). Este trabalho mostra que a informação contida no padrão de disparo, ou seja, na distribuição de IBSPs é codificada de forma não linear, com picos de informação característicos em determinadas partes do burst. Mostrou-se ainda que existe uma alta correlação entre os IBSPs destas células e a atividade no nervo que se projeta às áreas sensoriais do cérebro. Assim, este pode ser um mecanismo de controle do funcionamento da rede independente da resposta sensorial muscular.

Há evidências de que condutâncias de dinâmica lenta fornecem um mecanismo de memória de curto prazo (11-12). Turrigiano e colaboradores, por exemplo, mostraram que a cinética de uma condutância de sódio lenta fornece um mecanismo de memória celular capaz de lembrar de ativações (estímulos) ocorridos alguns segundos atrás. Tal mecanismo não envolve mudanças sinápticas, mas depende apenas das propriedades intrínsecas da célula. 
Por outro lado, nosso grupo investigou, através de simulações numéricas (ver seção 3.1 e referência (13)), o papel das condutâncias lentas das células do STG no mecanismo de codificação de IBSPs acima descrito. Os resultados indicam que os picos de informação transmitida são de fato sensíveis às propriedades dinâmicas das condutâncias. Entretanto, quando analisamos as alterações produzidas nestas condutâncias devido aos estímulos, observamos que são de amplitude bastante pequena. Tal fato levou-nos a questionar a existência deste mecanismo em neurônios biológicos onde as condutâncias estão sujeitas a ruídos intrínsecos, assim como outros tipos de ruídos devidos ao meio biológico.

Neste contexto, a interação de modelos com tecido vivo realizada através das técnicas de dynamic clamp (14-15) fornece um meio poderoso de investigação. Isto porque o método torna possível inserir condutâncias lentas artificiais em células, que não apresentam atividade lenta, e estudar a resposta da célula a estímulos controlados enquanto a condutância simulada evolui de maneira dinâmica. Neste sentido, a célula pode ser entendida como um simulador, fornecendo todos os parâmetros e condutâncias, exceto o controlado pelo experimentador.

Culturas de neurônios permitem estudar de maneira controlada como uma informação simples (na forma de um padrão de disparos) é transmitida de um neurônio para outro e também como uma determinada informação pode alterar a configuração sináptica de um circuito, formando memórias ou produzindo novos padrões (2). Este tipo de preparação é o que permite a maior flexibilidade ao experimentador, que pode controlar de maneira bastante razoável o comportamento de um neurônio. De forma particular, neurônios do molusco Aplysia sp. constituem um sistema quase ideal para estudos "in vitro" por diversos motivos: a preparação é bastante simples e rápida (16); a cultura dos neurônios removidos dos gânglios é bastante resistente e os neurônios in vitro facilmente reconectam-se através de sinapses (17).

Motivados por estas possibilidades, desenvolvemos em nosso laboratório, na primeira parte desta pesquisa, um protocolo adaptado para cultura de neurônios de Aplysia brasiliana. Os animais eram cedidos pelo CEBIMar/USP e mantidos em aquário com água 
marinha artificial. Durante este estágio desenvolvemos ferramentas para exposição e remoção das células, assim como métodos de assepsia. Apesar das culturas serem resistentes, o maior problema que tivemos, inicialmente, foram as contaminações por fungos. Para isso, construímos uma pequena capela de fluxo laminar e um suporte com fluxo vertical que permitia deslocar e acessar a placa de forma segura. Adicionando uma parte da hemolinfa dos próprios animais ao meio de cultura, observamos a regeneração dos axônios, obtendo diversas culturas saudáveis por cerca de semanas.

Dois fatores, entretanto, inviabilizaram os estudos com Aplysia em nosso laboratório. O primeiro deve-se ao fato dos animais serem extremamente sensíveis às condições do aquário e alimentares, o que dificultava a manutenção dos animais por tempos maiores que um mês. Além disso, os animais começaram a se distanciar do litoral de São Paulo por motivos ainda desconhecidos, tornando as coletas esporádicas e incertas.

Como alternativa às culturas, buscamos uma forma de adaptar um protocolo para o estudo de transmissão de informação em redes híbridas usando o STG. Nota-se que, nas preparações realizadas com o siri Callinects sapidus, é comum encontrarmos o ritmo trifásico do $C P G$ pilórico, embora não observemos atividade lenta, ou em bursts, no circuito gástrico. Em geral, as células gástricas disparam tonicamente ou são quiescentes in vitro. Desta forma, elas poderiam ser usadas para estudar os efeitos de condutâncias lentas inseridas artificialmente. Entretanto, inserir condutâncias lentas via dynamic clamp não é uma tarefa fácil. Isto porque a maioria das condutâncias lentas dependem da concentração intracelular de cálcio, que é de difícil acesso experimental. No entanto, a corrente do tipo H (18) depende apenas do potencial de membrana da célula e é caracterizada por ser ativa na fase hiperpolarizada dos bursts. Deste modo, está relacionada ao início das rajadas, despolarizando a célula, constituindo um mecanismo de controle das oscilações lentas (19).

Para investigar o efeito desta condutância na transmissão de informação, desenvolvemos um novo protocolo experimental baseado na técnica de dynamic clamp. Para isso, adaptamos uma versão do programa para simular uma condutância do tipo HodgkinHuxley e ler uma senóide de um gerador de sinais, inserindo a corrente correspondente à 
soma de ambos na célula. Nestas condições, o neurônio gástrico (originalmente tônico ou quiescente) passa a apresentar bursts com a mesma frequência da senóide. Deixamos a condutância evoluir dinamicamente durante um certo intervalo de tempo, durante o qual registramos em uma tabela os valores da condutância e da senóide - mantendo a relação de fase entre eles.

Em seguida, formamos um circuito híbrido adicionando um neurônio artificial $(A N)$ e uma sinapse química inibitória. O neurônio artificial é caracterizado por um sequência de bursts com distribuição aleatória de ISIs, que são disparados durante a fase hiperpolarizada do neurônio biológico. Para cada potencial de ação do neurônio artificial, o dynamic clamp simula e injeta a corrente pós-sináptica no neurônio biológico.

A resposta do neurônio biológico aos estímulo é registrada e analisada em dois ciclos. No primeiro, o computador lê a senóide do gerador e integra as equações diferenciais da condutância lenta em tempo real. Neste caso, os valores da condutância lenta evoluem de forma dinâmica, de acordo com o potencial de membrana da célula, sendo sensível às perturbações provocadas pelo estímulo (IPSPs). No segundo ciclo, repetimos o mesmo estímulo da etapa anterior, porém a corrente injetada na célula é proporcional à condutância e à senóide previamente gravadas na primeira etapa (sem estímulos). Embora o potencial de membrana evolua de maneira similar ao primeiro ciclo, os valores de condutância gravados são insensíveis às perturbações sinápticas.

Uma vez que os mesmos procedimentos são adotados nos dois ciclos acima descritos, a diferença entre eles é sutil e deve-se apenas ao caráter dinâmico da condutância lenta no primeiro caso. Assim, este protocolo permite que estudemos o papel das propriedades dinâmicas de condutâncias iônicas no processamento de informação. Chamamos este protocolo de "dissecação dinâmica de condutâncias iônicas".

Nossos experimentos indicam que, assim como para os neurônios do $C P G$ pilórico (10), a informação contida nos IBSPs é codificada de forma não linear com a formação de picos de informação mútua média (IMM) ao longo do burst de nosso neurônio híbrido. A posição dos picos, como mostraremos, depende de detalhes do modelo de condutância 
e da célula utilizada. Entretanto, o pico principal de informação mútua média entre as células é sensível à dinâmica da condutância lenta, desaparecendo para a condutância gravada. Assim, as propriedades dinâmicas das condutâncias lentas formam a base de um mecanismo biofísico que opera como uma memória de curto prazo, transmitindo a informação entre bursts através de uma única sinapse. 


\section{Metodologia}

\subsection{Os neurônios}

Todas as células possuem uma membrana plasmática com o intuito de isolar o conteúdo intracelular do meio externo. O que faz dos neurônios células especiais é a habilidade em alterar rápida e momentaneamente as propriedades de sua membrana gerando pulsos elétricos chamados potenciais de ação (spikes). Estes sinais são gerados de uma forma estereotipada tudo-ou-nada e podem se propagar por longas distâncias. Os potenciais de ação são as peças fundamentais no processamento e transmissão de informação nervosa. Os processos sensoriais, resultados da interação do organismo com o ambiente exterior, processamentos no sistema nervoso central e as respostas motoras são propagados pelos neurônios por meio dos spikes. Veremos nesta seção as propriedades básicas dos neurônios que viabilizam tal comportamento (20-22).

A membrana celular é formada por uma bicamada de fosfolipídeos. Estes são moléculas que possuem uma "cabeça" polar e "cauda" apolar. Em meios aquosos (polares), os fosfolipídeos se arranjam de forma que as caudas se isolem, formando uma região altamente hidrofóbica (figura 1), que possui permeabilidade quase nula a íons e moléculas polares grandes. No entanto, é necessário para o metabolismo celular trocar íons com o meio externo, mantendo determinados íons em concentrações adequadas dentro e fora da célula. O transporte de íons transmembrana acontece, basicamente, por dois processos: as bombas e os canais iônicos. As bombas funcionam de forma ativa, com consumo de energia (ATP), e são responsáveis por manter um grande desnível na concentração intra e extracelular de certos íons como, por exemplo, sódio e potássio. Os canais iônicos são estruturas proteicas especializadas no transporte passivo e seletivo dos íons. Em geral, 
como resultado destes mecanismos, o meio intracelular possui maior concentração de potássio $\left(K^{+}\right)$e ânions orgânicos $\left(A^{-}\right)$enquanto no meio extracelular há maior concentração de sódio $\left(\mathrm{Na}^{+}\right)$e cloro $\left(\mathrm{Cl}^{-}\right)$. Esta separação de íons provoca um pequeno desbalanço na quantidade de cargas dentro e fora da célula, gerando uma diferença de potencial definida por

$$
V_{m}=V_{\text {intra }}-V_{\text {extra }} .
$$

Em geral, o potencial de membrana em repouso é $V_{m}=-65 m V$. Outro efeito igualmente importante da separação de cargas é que ela cria uma capacitância intrínseca à membrana. Desta forma, um trecho de membrana pode ser modelado com o circuito elétrico equivalente mostrado na figura 1; sendo o capacitor equivalente à membrana, a resistência equivalente à permeabilidade dos canais iônicos e a bateria equivale ao potencial eletroquímico responsável pelo fluxo de íons.
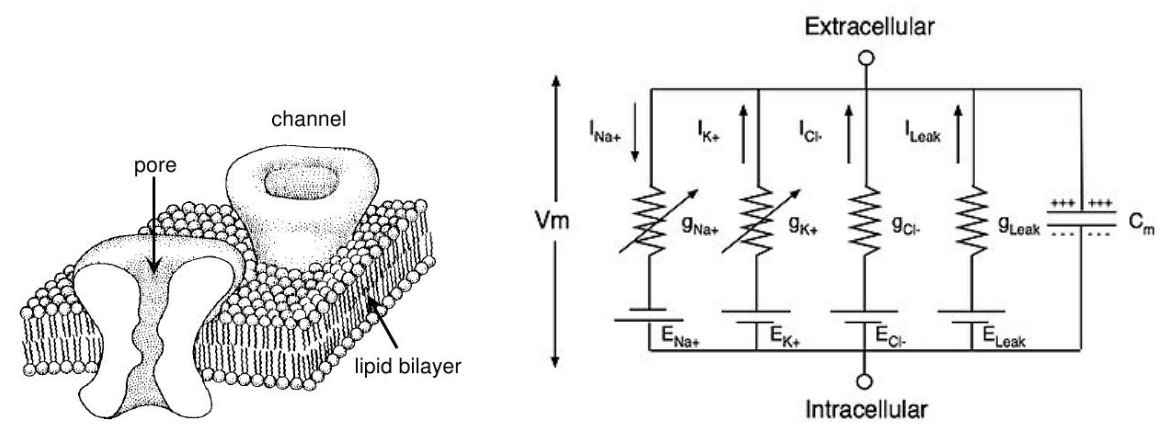

Figura 1 - Membrana plasmática e circuito elétrico equivalente. À esquerda mostramos o esquema simplificado de um trecho de membrana plasmática, evidenciando a bicamada lipídica e um canal iônico. À direita mostramos o circuito equivalente à membrana: o capacitor representa a membrana; cada canal iônico é modelado por meio de uma condutância e uma bateria, que representa o potencial eletroquímico. Figuras extraídas de (22) e (23).

O potencial de membrana em repouso pode ser explicado com base no equilíbrio das forças que agem sobre os íons. Para isso, considere uma membrana semipermeável que separa dois meios neutros com diferentes concentrações de um determinado íon. Neste caso, haverá um fluxo no sentido do gradiente de concentração, ou seja, da região de maior para a de menor concentração. Entretanto, o fluxo causa a separação de cargas e 
forma-se um potencial elétrico entre as duas regiões. O equilíbrio é atingido quando o potencial elétrico equilibra o efeito do gradiente de concentração. Este estado é conhecido como equilíbrio eletroquímico e o potencial no qual ele ocorre é dado, em função das concentrações interna e externa, pela equação de Nernst

$$
E_{I}=\frac{R T}{Z F} \ln \frac{[I]_{o}}{[I]_{i}}
$$

sendo $R$ a constante fundamental dos gases, $T$ a temperatura absoluta, $Z$ o número de valência do íon, $F$ a constante de Faraday e $[I]_{o} /[I]_{i}$ é a concentração externa/interna do íon. Se houver permeabilidade a vários íons, deve-se usar a equação de Goldman (20) para calcular o potencial de repouso da membrana. O potencial de Nernst de um tipo de íon é comumente chamado de potencial de reversão do íon. Para o potássio, por exemplo, o potencial de Nernst é $E_{K}=-75 m V$ e para o do sódio $E_{N a}=55 m V$. O potencial de repouso da membrana deve-se principalmente ao equilíbrio eletroquímico destes dois íons.

Os canais iônicos presentes na membrana são de extrema importância para o funcionamento dos neurônios, pois são capazes de momentaneamente alterar a permeabilidade da membrana à determinada espécie iônica. O entendimento do funcionamento microscópico dos canais iônicos foi possível devido à invenção da técnica experimental conhecida como patch-clamp (20). Nesta técnica, um eletrodo de vidro com ponta da ordem de micrômetros fixa-se à membrana celular. Mantendo-se uma diferença de potencial fixa, pode-se estudar a corrente que passa através de um único canal iônico ou de uma população. Desta forma, descobriu-se que os canais iônicos possuem um comportamento geral: podem estar em um estado fechado no qual não conduzem corrente, ou abrem e conduzem um valor fixo de corrente como mostrado na figura 2. A dinâmica de abertura e fechamento dos canais é estocástica e pode ser modelada em vários níveis (22, 24). Em geral, a probabilidade de um canal estar aberto depende do valor do potencial da membrana, da ligação de neurotransmissores ou mensageiros secundários e do tempo. A corrente que flui por determinado canal iônico é dada pela lei de Ohm 


$$
I_{i}=G_{i}\left(V-E_{i}\right)
$$

sendo $i$ a espécie iônica em questão, $V$ é o potencial de membrana em função do tempo e $E_{i}$ é o potencial de Nernst do íon. O valor máximo da condutância $G_{i}$, expresso em siemens, corresponde à fração de canais iônicos abertos.

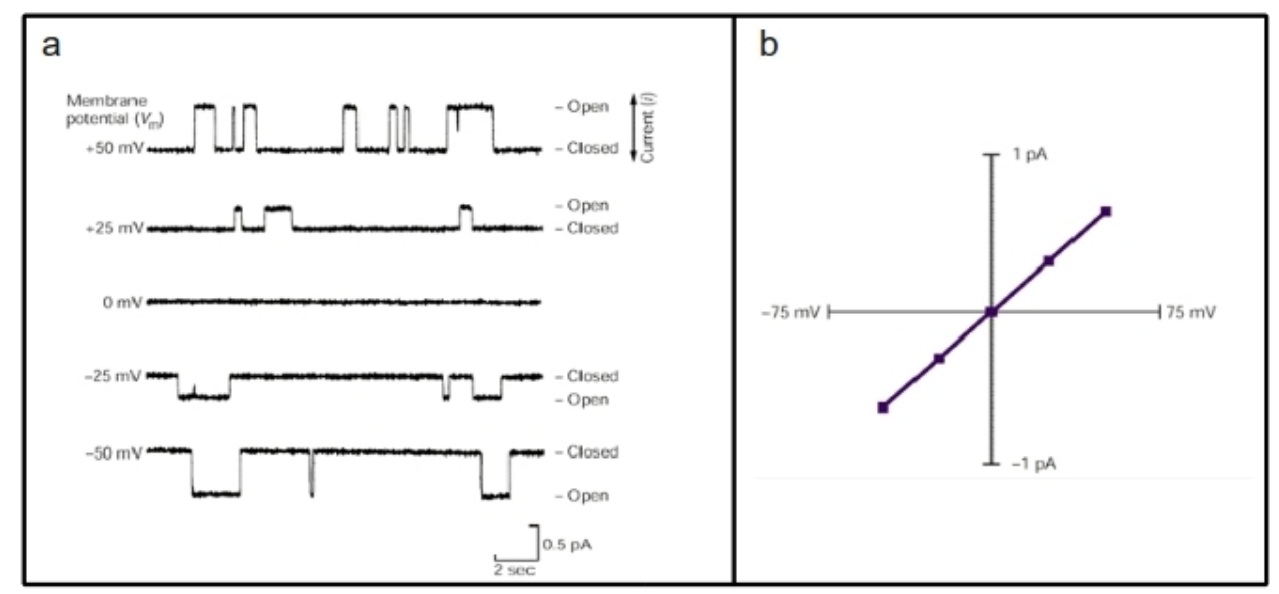

Figura 2 - Propriedades físicas dos canais iônicos. Em (a) mostramos a dinâmica de um dado canal iônico em função do potencial de membrana. Note que neste caso o potencial de reversão é de $0 \mathrm{mV}$. Quando o canal está aberto passa uma quantidade constante de corrente proporcional a $\left(V-E_{i}\right)$. Em $(\mathbf{b})$ mostramos a relação entre o potencial de membrana e a corrente que flui no canal. Esta é uma curva típica de resistores que obedecem à lei de Ohm. Dados obtidos para canais formados em membranas artificiais. Adaptado de (20).

\subsubsection{O modelo de Hodgkin-Huxley}

Os mecanismos iônicos responsáveis pela geração do potencial de ação foram elucidados por Hodgkin e Huxley em uma série de cinco artigos publicados em 1952 (1). As técnicas desenvolvidas nestes trabalhos constituem as bases de muitos estudos atuais. Os trabalhos de Hodgkin e Huxley foram possíveis graças ao tamanho e robustez de um axônio gigante encontrado na lula e da introdução da técnica de voltage-clamp (20). Nesta técnica, fixa-se o potencial de membrana e estuda-se a corrente que flui através de um 
trecho da membrana celular. Assim, foi possível separar e descrever a dinâmica das correntes de sódio e potássio, descrevendo suas dependências com o tempo e com o potencial de membrana.

Se um pequeno estímulo - um degrau de corrente, por exemplo - é apresentado ao axônio de forma a despolarizar ou hiperpolarizar a membrana, esta volta ao seu valor de repouso depois de um tempo característico. No entanto, se uma despolarização passa de um certo limiar (threshold) o axônio dispara um potencial de ação voltando ao repouso em seguida. Nota-se que após o potencial de ação existe um tempo refratário mínimo no qual não é possível excitar a célula novamente.

Hodgkin e Huxley mostraram que, quando a membrana é despolarizada, os canais de sódio abrem, provocando o fluxo de íons positivos para dentro da membrana. Este fluxo, por sua vez, causa a abertura de mais canais iônicos gerando um comportamento explosivo que em frações de milissegundos leva o potencial de membrana de $-65 \mathrm{mV}$ a $50 \mathrm{mV}$. Para valores elevados do potencial de membrana, entretanto, abrem-se os canais de potássio, gerando um fluxo de íons positivos para fora da célula, hiperpolarizando-a novamente.

Os canais de potássio possuem dois estados (aberto e fechado). Além destes estados, os canais de sódio possuem um estado adicional que chamamos inativado. Uma vez que um canal de sódio está aberto, existe a possibilidade de ele ser inativado, bloqueando a passagem de íons. Quando a célula é hiperpolarizada, os canais de sódio fecham e são desinativados.

Matematicamente, quando o número de canais iônicos tende a infinito e os efeitos estocásticos podem ser desprezados, o potencial de membrana em função do tempo é descrito por

$$
\tau_{m} \frac{d V}{d t}=G_{L}\left(V-E_{L}\right)+G_{K} n^{4}\left(V-E_{K}\right)+G_{N a} m^{3} h\left(V-E_{N a}\right)+I .
$$

O termo $G_{L}$ é chamado condutância de vazamento (leakage) e representa diversos pro- 
cessos que contribuem para a corrente e são aproximadamente constantes ao longo do tempo. A variável $I$ corresponde à corrente total injetada por eletrodos intracelulares e $\tau_{m}$ é constante de relaxação da membrana celular. O $n$ e o $m$ são chamados variáveis de ativação e estão relacionados às probabilidades de abertura dos canais e $h$ é a variável de inativação para o canal de sódio. Estas variáveis dependem do tempo e do potencial de membrana e variam entre 0 e 1 de acordo com a seguinte equação:

$$
\frac{d i}{d t}=\alpha_{i}(V)(1-i)-\beta_{i}(V) i
$$

sendo que $i$ representa uma das variáveis $n, m$ ou $h$. As variáveis $\alpha_{i}$ e $\beta_{i}$ descrevem as taxas de transição entre os estados aberto e fechado em função do potencial de membrana e são descritas por funções exponenciais ou sigmoidais (ver (22)). É comum encontrar na literatura a seguinte transformação

$$
i_{\infty}=\frac{\alpha_{i}(V)}{\alpha_{i}(V)+\beta_{i}(V)} \quad \text { e } \quad \tau_{n}=\frac{1}{\alpha_{i}(V)+\beta_{i}(V)},
$$

com a qual a equação (2.5) pode ser reescrita da seguinte maneira

$$
\tau_{i} \frac{d i}{d t}=i_{\infty}-i
$$

Neste caso, $i_{\infty}$ é a probabilidade de que uma subunidade esteja no estado aberto (ou inativo, para $h$ ) para um determinado potencial de membrana quando o tempo vai para infinito e $\tau_{i}$ é constante temporal do canal iônico. Na figura 3, mostramos o comportamento das grandezas $i_{\infty}$ em função do potencial de membrana encontradas por Hodgkin e Huxley.

Embora o modelo de Hodgkin-Huxley acima descrito seja suficiente para explicar os comportamentos observados no axônio gigante da lula, não explica a variedade e complexidade de padrões observados em muitas células nervosas. Isto deve-se à existência de outros tipos de canais iônicos como, por exemplo, os canais que transportam cálcio e canais de sódio dependentes da concentração de cálcio. Além disso, os canais são distribuídos de maneira não uniforme ao longo da célula. De um ponto de vista dinâmico, os canais iônicos 


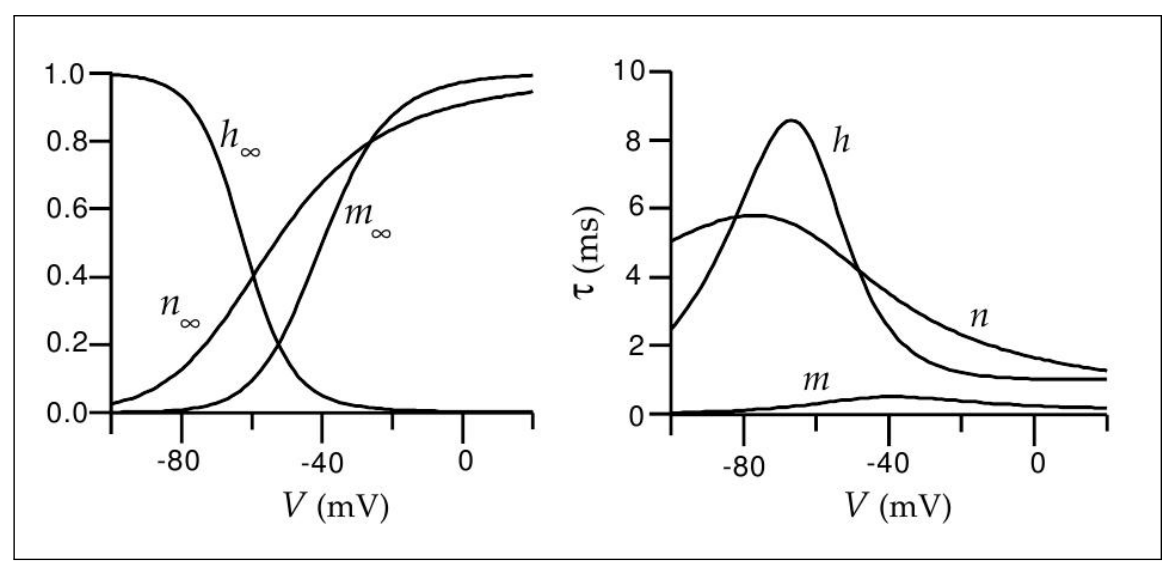

Figura 3 - Estado estacionário das variáveis de ativação e inativação do modelo de Hodgkin e Huxley. À esquerda mostramos as variáveis de ativação $\left(m_{\infty}\right)$ e inativação para o sódio e da variável $\left(h_{\infty}\right)$ de ativação do potássio $\left(n_{\infty}\right)$. À direita mostramos o comportamento das constantes temporais. Figura retirada da referência (22)

podem ser classificados em dois grupos: os de dinâmica rápida e os de dinâmica lenta. Em geral, os canais de dinâmica rápida são responsáveis pela geração dos potenciais de ação, enquanto os de dinâmica lenta são responsáveis pelas oscilações lentas que compõem os disparos em rajadas de potenciais de ação ou bursts. Estes são caracterizados por uma sequência de potenciais de ação que ocorrem durante um patamar de despolarização seguido por um período de hiperpolarização. A figura 4 mostra alguns comportamentos típicos das células nervosas.

\subsection{O sistema nervoso estomatogástrico de crustá- ceos}

Os crustáceos (artrópodes decápodes) distinguem-se pelo hábito de, como uma forma de fuga, cortar e engolir os alimento em pedaços grandes, sendo a mastigação posteriormente realizada no estômago, que possui três dentículos e uma musculatura apropriada. 


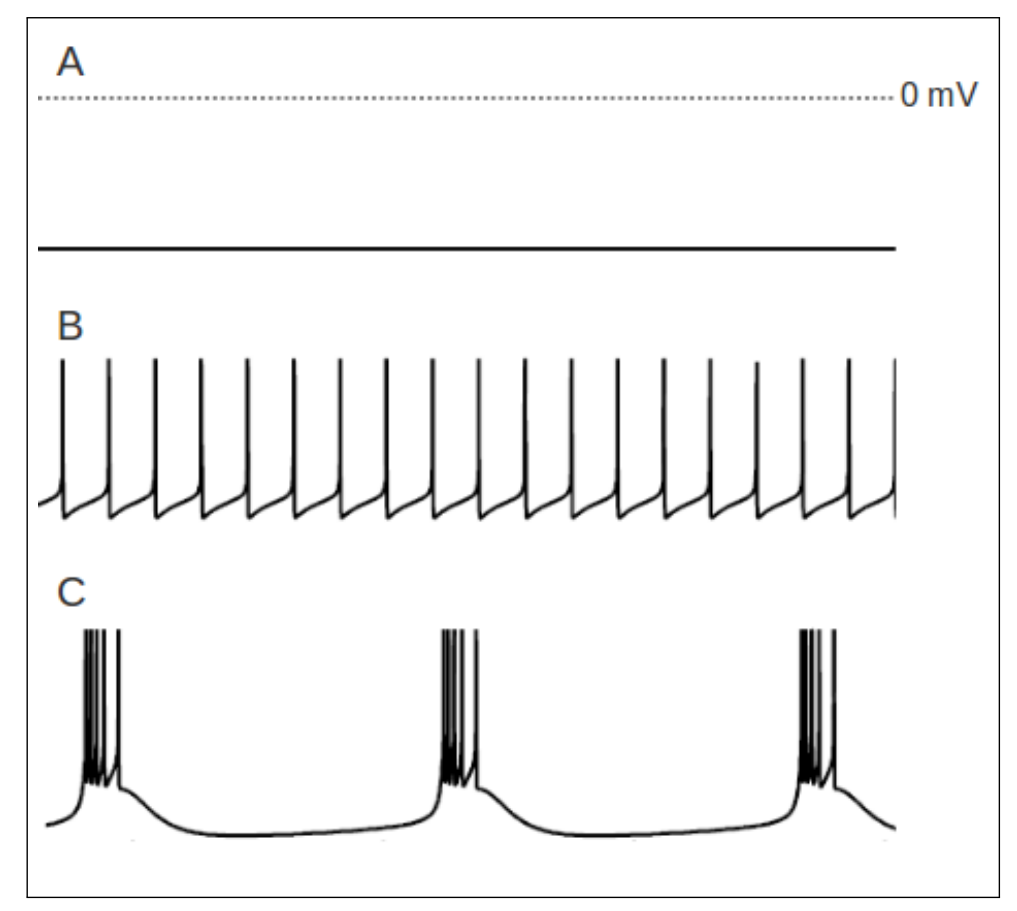

Figura 4 - Tipos de comportamento elétrico das células nervosas. (A) Comportamento quiescente: não dispara potenciais de ação na ausência de estímulos. (B) Comportamento tônico: dispara potenciais de ação em intervalos aproximadamente regulares. (C) Comportamento em rajadas: dispara trens de potenciais de ação (bursts) seguidos por períodos de hiperpolarização. Traços obtidos de neurônios modelos, adaptado de $(22)$.

O sistema nervoso estomatogástrico (25), constituído por cerca de 30 neurônios, é o responsável pela geração e controle de tais movimentos.

Na figura 5 mostramos um esquema do estômago e a posição relativa do sistema nervoso estomatogástrico composto por dois gânglios comissurais $(C G)$, um gânglio esofágico $(O G)$ e o gânglio estomatogástrico $(S T G)$ localizado na superfície dorsal do estômago. O STG se conecta aos gânglios superiores, que se conectam ao cérebro através do nervo estomatogástrico (stn); enquanto o nervo motor (dvn) parte do gânglio e se bifurca para inervar os músculos alvos.

O que faz do STG um sistema quase ideal para estudos in vitro é que a rede mantém os mesmos ritmos motores por até 12 horas após isolada do animal, desde que se mantenha as conexões com os gânglios superiores (5). Somam-se ainda alguns fatores importantes: os neurônios são grandes comparados aos dos outros animais, permitindo 


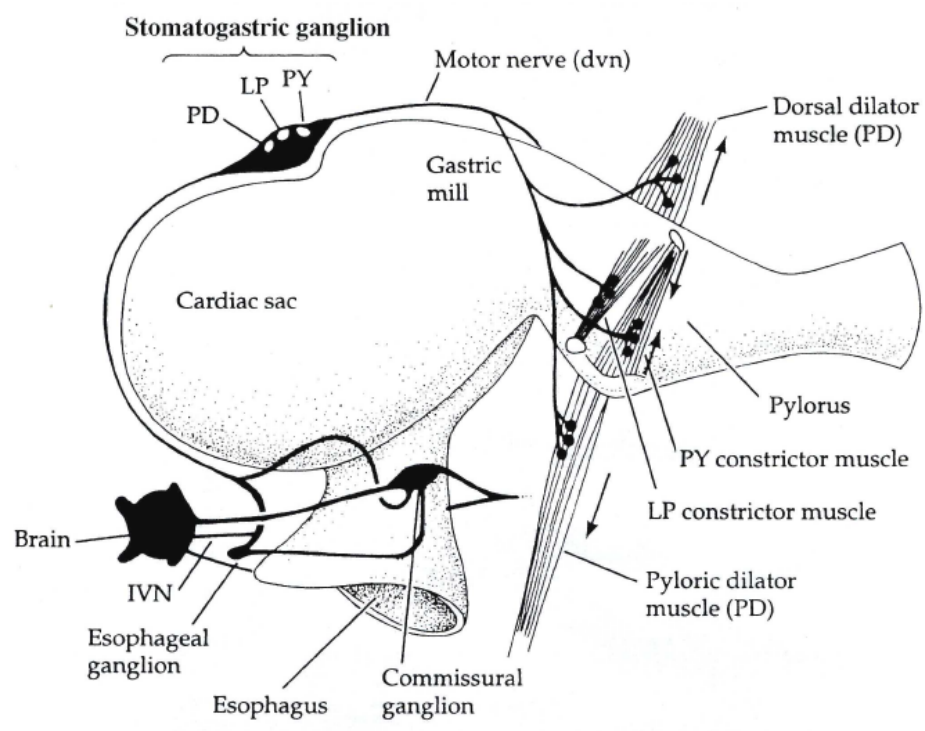

Figura 5 - Esquema do estômago e a posição relativa do sistema nervoso, consistindo de dois gânglios comissurais $(C G)$, o gânglio esofágico $(O G)$ e o gânglio estomatogástrico $(S T G)$. São mostrados alguns dos nervos principais que fazem a conexão do gânglio estomatogástrico com os gânglios superiores, bem como algumas ramificações do nervo motor inervando alguns dos músculos pilóricos. Cortesia de R. Elson.

medidas intracelulares com dois eletrodos; são identificáveis, o que permite fazer o mesmo experimento em animais diferentes e a rede é pequena, possibilitando o mapeamento de todas as conexões sinápticas.

O STG é capaz de produzir in vitro parte dos padrões observados in vivo porque é composto por pequenos circuitos chamados geradores centrais de padrão $(C P G)$, que são circuitos especializados em produzir ritmos robustos independentemente de interferência rítmica proveniente do cérebro. Como controle, o circuito recebe neuromodulação dos gânglios superiores. No STG dos crustáceos estão presentes dois CPGs: o gástrico, que controla os movimentos de mastigação e dos dentes na moela gástrica; e o pilórico, que controla o bombeamento de comida para o intestino no piloro. Em preparações in vitro do $S T G$ de siris azuis, o $C P G$ pilórico apresenta o mesmo ritmo observado in vivo, enquanto os neurônios do $C P G$ gástrico não produzem ritmo: alguns são encontrados em estado quiescente e outros disparam tonicamente. Um esquema das células contidas nos dois circuitos e suas conexões sinápticas são mostradas na figura 6. 


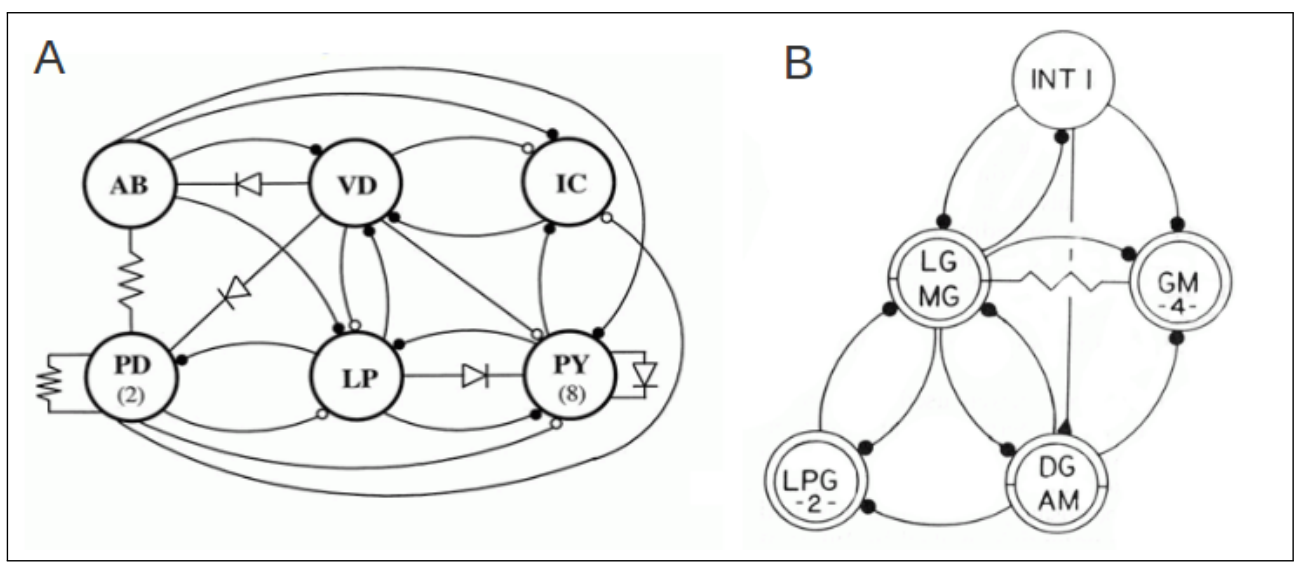

Figura 6 - Esquema simplificado dos $C P G s$ do $S T G$. A . CPG pilórico: controla o bombeamento de comida no piloro. B $C P G$ gástrico: responsável pelos movimentos de mastigação da moela gástrica. As sinapses inibitórias são representadas por círculos. Os resistores representam as sinapses elétricas e os diodos representam sinapses elétricas retificadoras. Figuras extraídas de (26).

\subsection{Dissecação do sistema estomatogástrico}

Os animais (figura $7 a$ ) são previamente retirados do aquário e anestesiados por imersão em gelo por aproximadamente 30 minutos. O processo de dissecação inicia-se removendo as patas e fazendo-se uma pequena abertura na parte dorso-frontal do exoesqueleto. Através desta abertura, cuidadosamente separamos a pele interior do exoesqueleto. Este procedimento é necessário porque a artéria oftálmica, que faz a circulação do coração ao cérebro, está fisicamente ligada à pele interior e ao $S T G$. Retiramos a parte dorsal do exoesqueleto que recobre o estômago, que é finalmente exposto retirando-se parte da pele interior como pode ser visto na figura $7 b$. O esôfago é desconectado da carapaça com o auxilio de uma pinça curva e de uma pequena tesoura. Em seguida, cortamos as conectivas circumesofágicas e, levantando o estômago, quebram-se normalmente as conexões com o intestino e o hepatopâncreas. O estômago é finalmente removido cortando-se a artéria oftálmica na parte posterior do estômago e as conexões restantes. O estômago é então lavado em solução fisiológica (14) repetidas vezes a fim de eliminar o suco gástrico. Esta etapa da preparação leva cerca de 20 minutos. 
Segurando o estômago pela parte superior do esôfago, fazemos um corte ventral simétrico da abertura do esôfago até o piloro. Fazemos ainda dois cortes laterais na direção dos ossículos e cortamos os dentículos da moela gástrica, de forma que o estômago adquira um formato plano na placa de dissecação. Por fim, fixamos o estômago à placa de dissecação preenchida com solução salina adequada e recoberta com cera escura para facilitar a visualização dos tecidos (figura $7 c$ ) . Nesta etapa, a preparação contém a musculatura completa do estômago, os gânglios supraesofágicos, o sistema estomatogástrico completo, as comissurais circumesofágicas e o cérebro. Esta etapa leva cerca de 5 minutos.

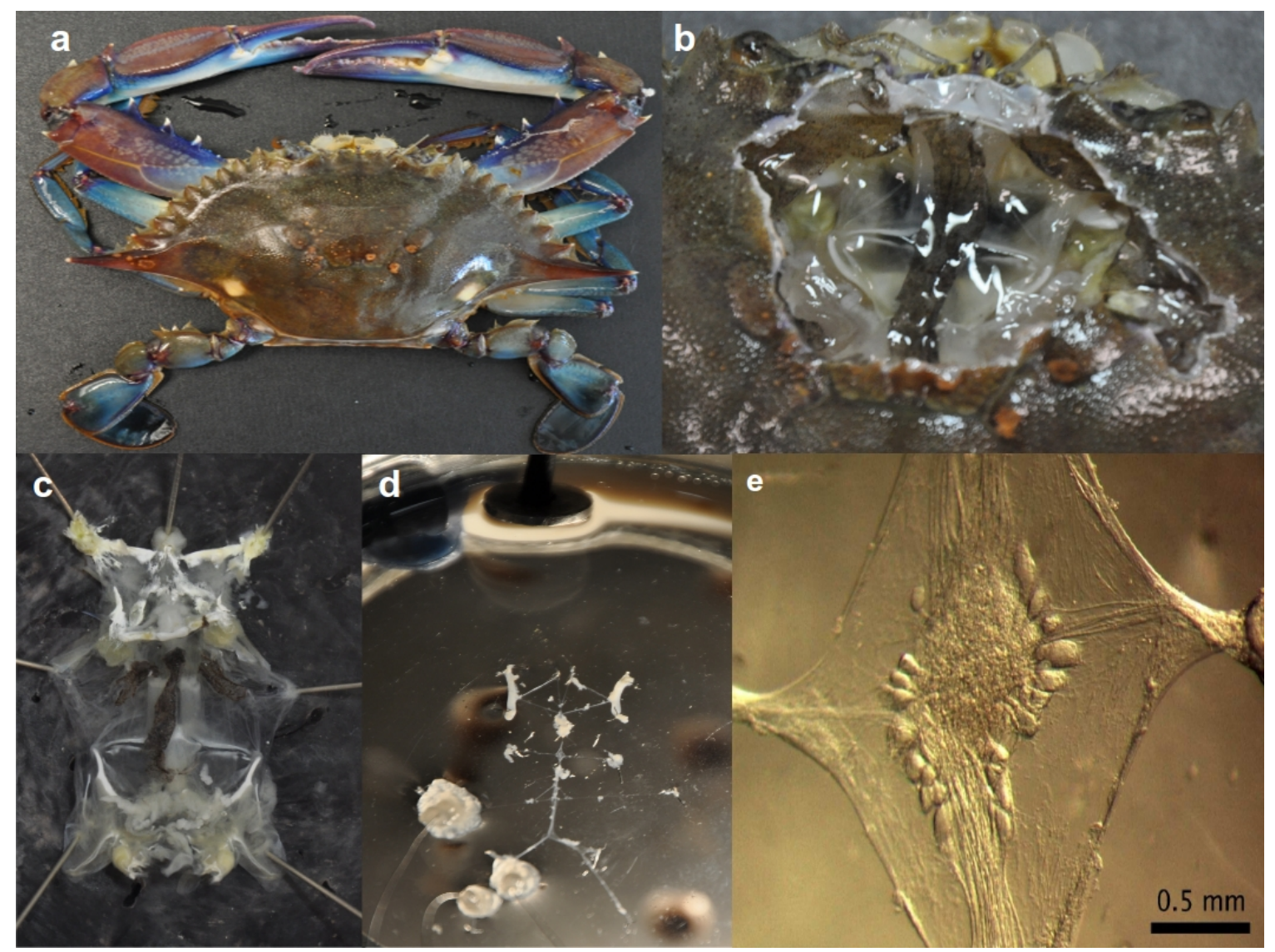

Figura 7 - $\quad$ Preparação biológica. a O siri azul após anestesia por infusão em gelo. b O estômago é exposto retirando-se uma parte dorsal do exoesqueleto e cortando a pele interior. Note que deixamos a parte central da pele interior inicialmente intacta para preservar a artéria oftálmica. c Estômago aberto, contendo o $S T G$ e o cérebro, fixado à placa de dissecação com pinos de aço inox. d Nervos do sistema estomatogástrico em placa de Petri preenchida com solução fisiológica adequada pronta para medidas intra ou extracelular. É possível ver eletrodos extracelulares isolados por ilhas de vaselina na parte inferior esquerda. e O gânglio estomatogástrico visto ao microscópio. Os corpos celulares se distribuem na região externa ao gânglio.

Utilizando um microscópio estereoscópico, pinças e tesouras para microcirurgia os 
nervos são identificados — de acordo com a posição relativa aos músculos que inervam — e isolados. Os nervos stn e $s d n$ são isolados até o ponto onde entram na artéria oftálmica. Uma vez removidos os músculos e os tecidos gordurosos e cortadas as terminações nervosas que não serão utilizadas, o sistema nervoso estomatogástrico é transferido para uma placa de Petri preenchida com solução fisiológica e revestida de um silicone transparente (Silgard 184, Dow Corning). Os nervos são fixados à placa com pinos de aço inox na mesma posição relativa que ocupavam no estômago (Figura $7 d$ ). Neste ponto, fazemos uma limpeza mais fina nos nervos em que serão realizadas medidas extracelulares removendo os tecidos remanescentes. Em seguida, abrimos a artéria oftálmica, isolamos os nervos aln dos tecidos próximos e expomos o gânglio estomatogástrico. Finalmente, devemos remover a fina camada de tecido conectivo que recobre o gânglio, expondo os corpos celulares para medidas intracelulares (Figura 7e). Esta parte final da preparação leva entre 2 e 5 horas dependendo do tamanho do espécime e da quantidade de tecido gorduroso presente.

\subsection{Dynamic Clamp}

O método conhecido como dynamic clamp $(14,27)$ consiste em introduzir artificialmente condutâncias iônicas ou sinápticas em neurônios. Para isso, equações diferencias que descrevem o comportamento das condutâncias são resolvidas em tempo real em um computador conectado às células. A implementação deste protocolo consiste na repetição de um ciclo com os seguintes passos:

1. O potencial de membrana do neurônio é medido por amplificadores intracelulares conectados a uma placa de conversão analógico-digital (ADC) e coletado pelo computador; 
2. O potencial lido é usado como entrada nas equações do modelo simulado, que são integradas em tempo real. Como resultado, temos a corrente total que deve ser injetada na célula num dado instante de tempo;

3. As tensões de saídas proporcionais às correntes a serem injetadas são enviadas ao conversor digital-analógico (DAC) e a corrente enviada ao amplificador é finalmente injetada nas células através de eletrodo intracelular.

Esse ciclo é repetido continuamente durante o experimento, possibilitando que os valores de condutância evoluam dinamicamente de acordo com o potencial de membrana da célula ou de um neurônio pós-sináptico. Um ponto essencial para o método é que os ciclos sejam repetidos a elevadas taxas, de forma que a célula não perceba que as atualizações são feitas em tempos discretos. Em nosso caso, particularmente, conseguimos taxas de atualizações entre 5 e $30 \mathrm{KHz}$.

Entre as diversas aplicações de dynamic clamp podemos citar:

- Introdução, modificação e até supressão de condutâncias particulares. Tais experimentos podem ser feitos em conjunto com técnicas farmacológicas nas quais determinados canais são bloqueados e depois simulados, ou condutâncias são geradas para cancelar o efeito de canais que não podem ser bloqueados. A adição de condutâncias antes inexistentes em uma determinada célula permite estudar o efeito dessa condutância em função dos parâmetros usados sem se preocupar com as demais condutâncias. Neste sentido, a célula pode ser vista como um simulador.

- Simulação de sinapses entre neurônios biológicos, permitindo refazer sinapses que tenham sido quimicamente bloqueadas e estudar suas propriedades de acordo com modelos/parâmetros ou adicionar sinapses em uma rede. Existe, ainda, a possibilidade de interagir neurônios biológicos com modelos através de sinapses artificias criando redes híbridas.

A maior limitação do protocolo de dynamic clamp é que as correntes são produzidas de forma puntual no corpo celular, impossibilitando simular a distribuição espacial dos 
canais iônicos. Uma revisão das implementações recentes e aplicações pode ser encontrada em (15), bem como no recente livro (28).

\subsection{Teoria da informação}

A teoria da informação foi desenvolvida por Shannon (29) para quantificar a capacidade de códigos ou canais de comunicação em transmitir informação. Definimos, neste sentido, um canal de informação como sendo constituído de emissor, receptor e fontes de ruído. Em neurociência, a teoria de informação é utilizada para quantificar a confiabilidade das correlações estímulo-resposta em diversas situações experimentais (30-31). A grande vantagem do método é que não é necessário fazer hipótese alguma sobre o código neural utilizado pelas células. Desta forma, a quantidade de informação transmitida por um estímulo particular pode ser estimada apenas calculando as distribuições de probabilidade dos pares estímulo-resposta em séries temporais longas.

Se um evento $r$ ocorre com probabilidade $P(r)$, definimos o seu conteúdo informacional como

$$
i(r)=-\log _{2} P(r)
$$

Usamos o logaritmo na base 2 de acordo com a escolha da unidade arbitrária bit (0 ou 1). Esta definição está de acordo com o senso comum de que eventos menos prováveis transmitem mais informação. Temos ainda que a informação transmitida por eventos independentes deve ser igual à soma das informações dos eventos. Isto justifica, e limita, a escolha da função logaritmo para medida de informação.

Definimos a entropia como sendo a informação média sobre o conjunto de todos os 
eventos possíveis, $R=\left\{r_{1}, r_{2}, \ldots, r_{n}\right\}$,

$$
H(R)=-\sum_{r} P(r) \log _{2} P(r)
$$

Intuitivamente, a entropia fornece uma medida da variabilidade do sistema. A entropia será máxima se todos os estados forem igualmente prováveis e será nula se o sistema permanecer em um único estado. Assim, a entropia é uma quantidade sempre positiva.

Para que um determinado neurônio ou rede neural transmita informação sobre um conjunto de estímulo, é necessário que a variabilidade da resposta esteja correlacionada com mudanças no estímulo. Considerando um estímulos $s$ pertencente ao conjunto $S$ e uma resposta $r$ do conjunto $R$, definimos a informação mútua entre dois eventos como sendo

$$
i(s, r)=-\log _{2} \frac{P(s, r)}{P(s) P(r)},
$$

sendo $P(s, r)$ a probabilidade conjunta de se observar o estímulo $s$ e a reposta $r$. Se os eventos forem independentes $P(s, r)=P(s) P(r)$ e a informação mútua é nula. Por fim, definimos a Informação Mutua Média (IMM) como sendo a média da informação mútua sobre todos os eventos possíveis

$$
\operatorname{IMM}(S, R)=-\sum_{s, r} P(s, r) \log _{2} \frac{P(s, r)}{P(s) P(r)} .
$$

A informação mútua média é uma grandeza positiva e simétrica em relação aos conjuntos $R$ e $S$, ou seja, $\operatorname{IMM}(S, R)=\operatorname{IMM}(R, S)$. Deste modo a IMM não indica o sentido do fluxo de informação, mas apenas quantifica a quantidade de informação trocada. Se definirmos ainda a entropia da resposta dado um certo estímulo como

$$
H(R \mid S)=-\sum_{r} P(r \mid s) \log _{2} P(r \mid s),
$$

a equação (2.11) pode ser reescrita, após alguns rearranjos, como

$$
I M M(S, R)=H(R)-H(R \mid S) .
$$


Quando apresentamos um determinado estímulo $s$ repetidamente, esperamos que a variabilidade do conjunto de resposta seja reduzida, se o estímulo for de fato codificado. Se o sistema não tivesse ruído, esperaríamos sempre a mesma resposta e a entropia da resposta dado o estímulo seria nula. Por isso, às vezes, a grandeza dada em (2.12) é chamada de entropia de ruído, ou seja, é a variabilidade devido a outras fontes que não sejam o estímulo. Assim, a equação (2.13) possui a interpretação intuitiva de que a IMM é a redução na variabilidade do conjunto de resposta devido à apresentação de um dado estímulo.

Embora a teoria da informação seja matematicamente rigorosa, não há uma forma única e clara de aplicá-la à neurociência. Tal arbitrariedade vem das várias possibilidades de se definir os conjuntos de estímulo e resposta. A maioria dos métodos usuais (30-31) são dedicados a trens de potenciais de ação, sendo considerado como evento o tempo de ocorrência de cada potencial de ação.

Para analisar séries temporais de neurônios que disparam em rajadas de potenciais de ação, nosso grupo tem desenvolvido o protocolo $(10,13)$ que apresentaremos a seguir. Considerando que temos uma séries de bursts estímulo e bursts resposta, consideramos um par conjunto estímulo-resposta (joint-burst) quando há uma relação de causalidade entre eles, ou seja, a resposta ocorre logo após o estímulo e este termina antes do final da resposta. Dada a série temporal de dois neurônios, identificamos todos os pares conjuntos possíveis e os colecionamos.

Em seguida, para codificar o tempo dos disparos, devemos escolher uma origem temporal. Em geral, elegemos como origem o primeiro spike do burst do neurônio de resposta em cada par. Fazemos tal escolha porque, nos experimentos com o $C P G$ pilórico, tais neurônios são células eletricamente ligadas a marcapassos e, portanto, possuem uma certa periodicidade. Calculando o tempo de ocorrência de todos os disparos para todos os pares, obtemos uma distribuição estatística. Esta distribuição possui os valores limites: início da distribuição de estímulo $s_{s}$, final do estímulo $e_{s}$ e final da distribuição da resposta $e_{r}$ - note que o começo da distribuição de resposta é fixo devido à escolha da origem. 
A cada distribuição de estímulo e de resposta atribuímos uma string com um grande número de bins de tamanho $\Delta T$. Atribuímos o valor 1 a cada bin correspondente ao tempo de ocorrência de um spike e 0 aos demais. Dois ponteiros $i$ e $j$-correspondendo ao $i$-ésimo e ao $j$-ésimo bit (ou bin) dos bursts de estímulo e resposta, respectivamente são usados para designar a posição dentro do burst.

Para cada par dos ponteiros $(i, j)$, uma palavra com $n$ bits é extraída (Figura 8), formando um conjunto de estímulos $S_{i}^{1}=\left\{W_{s, i, 1}^{1}, W_{s, i, 2}^{1}, \ldots, W_{s, i, N}^{1}\right\}$ e um conjunto de respostas $R_{j}^{1}=\left\{W_{r, j, 1}^{1}, W_{r, j, 2}^{1}, \ldots, W_{r, j, N}^{1}\right\}$, sendo $N$ o número total de bursts na série temporal e o 1 sobrescrito está relacionado ao tamanho da palavra, como mostraremos adiante. Assim, a primeira palavra do conjunto de estímulos, $W_{s, i, 1}^{1}$, corresponde à sequência de $n$ bits começando no bit $i$ do burst de estímulo no primeiro par. A segunda palavra, $W_{s, i, 2}^{1}$, está na mesma posição no segundo par e assim por diante. Calculando a probabilidade de ocorrência das palavras nos conjuntos $S_{i}^{1}$ e $R_{j}^{1}$, podemos calcular as entropias $H\left(S_{i}^{1}\right)$ e $H\left(R_{i}^{1}\right)$, ou seja, obtemos a entropia do estímulo e da resposta de acordo com a posição nos bursts.

O procedimento anterior é repetido variando-se o tamanho dos bins. Para isso, usamos um parâmetro de reamostragem $k$, de forma que os bins fiquem com tamanho $b=k \Delta t$ (Figura 8). Novamente, é atribuído 1 aos bins que contém spikes e 0 aos demais. Para cada posição $(i, j)$, formamos os conjuntos de estímulo $S_{i}^{k}$ e resposta $R_{j}^{k}$ e calculamos a entropia novamente. Repetindo este procedimento para valores crescentes de $k$, escolhemos o tamanho de bin que maximiza a entropia por posição no burst.

Uma vez determinado o bin que maximiza a entropia, suponhamos $k=K$ para o estímulo e $k=K^{\prime}$ para a resposta, os conjuntos $S_{i}^{K}$ e $R_{j}^{K^{\prime}}$ são utilizados para calcular as probabilidades conjuntas de se observar os pares de estímulo-resposta $\left(W_{s, i, m}^{K}, W_{r, j, m}^{K^{\prime}}\right)$ para todos os valores possíveis de $i, j$ e $m$. Obtemos assim uma matriz com os valores de IMM entre todas as partes dos bursts de estímulo e resposta. Finalmente, para facilitar a análise, convertemos os índices $(i, j)$ para seus respectivos valores temporais.

Por fim, para confirmar a significância estatística da IMM calculada e descartar efeitos 


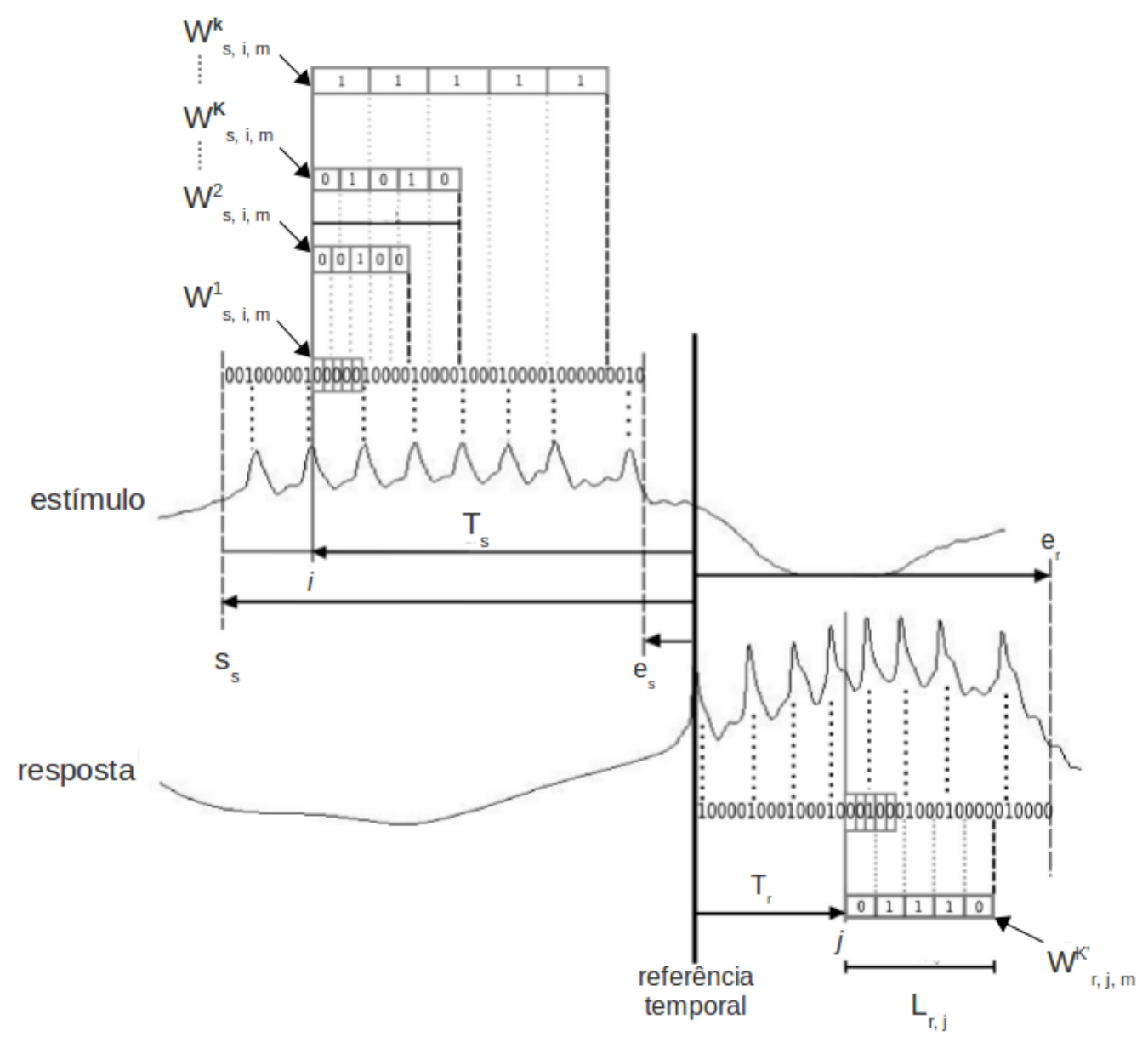

Figura 8 - Digitalização dos dados. Esquema para o $m$-ésimo par estímulo-resposta. A referência temporal é definida no primeiro spike do burst de resposta para cada par. Os limites $\left(s_{s}, e_{s}\right)$ e $\left(s_{r}, e_{r}\right)$ são obtidos calculando-se a distribuição de spikes sobre todos os pares. Definimos inicialmente uma string com bins de tamanho $\Delta T$, sendo atribuído 1 aos bins que contém spikes e 0 aos demais. Forma-se palavras de tamanho $n$ bits ( $n=5$ neste caso), cujos inícios são indicados pelos índices $i$ e $j$. O tamanho das palavras é variado utilizando um parâmetro de reamostragem $k$ como o objetivo de encontrar o tamanho do bin que maximiza a entropia por posição no burst. Figura adaptada de (10).

intrínsecos das distribuições e do método adotado, adaptamos um método conhecido por surrogate (32). Neste método, para cada burst resposta escolhemos aleatoriamente um novo burst pergunta. Desta forma, temos o mesmo conjunto de estímulo e resposta, mas quebramos a relação de causalidade entre os pares. Com a série embaralhada, repetimos toda a análise anterior, obtendo novos valores de IMM. Tal procedimento é repetido várias vezes e, por final, calculamos a média aritmética da IMM obtida em cada simulação embaralhada, que chamaremos de $I M M_{\text {surr }}$. 
De forma a tornar a análise mais direta definimos a seguinte grandeza que chamaremos IMM relativa

$$
I M M_{\text {rel }}=\frac{I M M-I M M_{\text {surr }}}{H(R)} .
$$

No numerador subtraímos da IMM os valores obtidos das séries embaralhadas e dividimos o resultado pela entropia do conjunto de resposta. Esta grandeza representa a fração da variabilidade da resposta destinada a codificar o estímulo. 


\section{Desenvolvimento}

\subsection{Dissecação dinâmica em tempo real}

As técnicas de patch clamp (20) permitiram medir as correntes devidas a um único canal iônico. Adaptações desta técnica, como os chamados "tail current protocols", aliadas a simulações computacionais, tornaram possível estudar as propriedades dinâmicas destas condutâncias ajustando-as em equações do tipo Hodgkin-Huxley (ver, por exemplo, (19)). Cada condutância é descrita por cerca de quatro equações diferenciais e se acoplam às demais condutâncias do modelo através da equação que descreve a evolução temporal do potencial de membrana. Embora conheçamos as equações das condutâncias, não conhecemos o papel de cada uma em processos gerais, como por exemplo, no processamento de informação. Isolar o papel de uma dada dinâmica não é trivial, pois a interação com as demais pode trazer comportamentos emergentes não lineares.

Motivado por tais questões nosso grupo realizou simulações computacionais com o objetivo de estudar o papel da dinâmica de cada canal iônico (13). Para isso, simula-se um modelo de neurônio do $C P G$ e grava-se os valores de uma condutância lenta por certo tempo. Faz-se então uma simulação computacional na qual o neurônio interage com um outro modelo através de uma sinapse inibitória e todas as equações são integradas normalmente. Em seguida, repete-se a simulação anterior porém substituindo as equações das condutâncias lentas pelos valores previamente gravados. Nos dois casos, estuda-se a quantidade de informação, IMM, trocada entre os dois neurônios. Este protocolo de simulação permite isolar o efeito da dinâmica de uma única corrente lenta no processamento de informação. Alguns resultados são mostrados na figura 9. Nota-se que há picos de informação ao longo da rajada de potenciais de ação que são dependentes da dinâ- 
mica das correntes lentas, uma vez que os mesmo desaparecem completamente quando a condutância é substituída por valores pré-gravados.
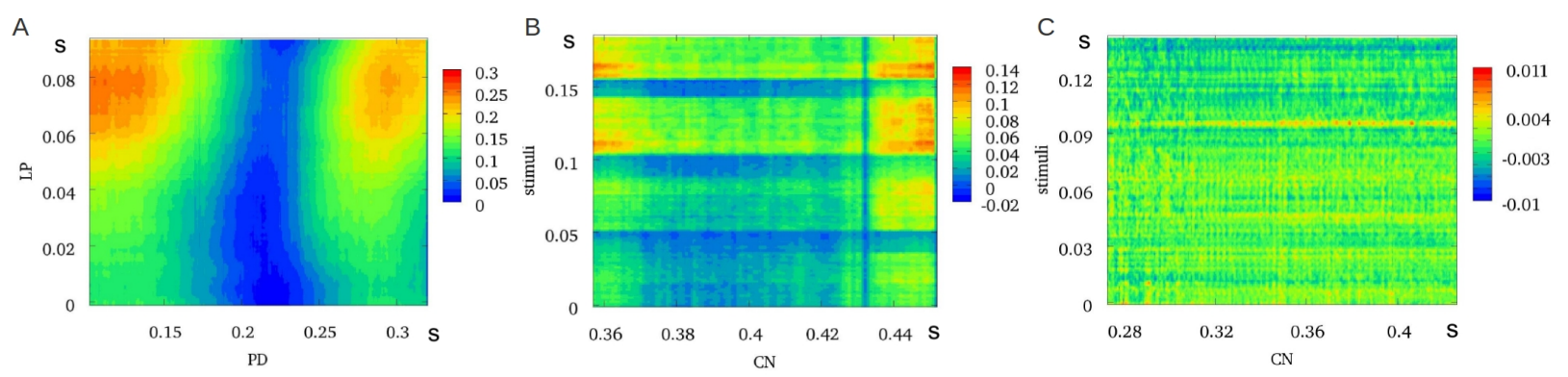

Figura 9 - $\quad$ Análise do fluxo IMM no $C P G$ pilórico e em simulações numéricas. A IMM obtida experimentalmente para os neurônios LP e PD do $C P G$ pilórico. Nota-se picos de informação entre o final do LP e o início e final do PD. B Resultados obtidos através de simulação numérica usando modelo de células do $S T G$. Nesta parte todas as condutâncias do modelo são integradas simultaneamente e os picos de informação ocorrem em regiões semelhantes ao caso LP-PD. C Resultados obtidos em simulações numéricas com condutâncias previamente gravadas. Neste caso, os picos de informação desaparecem completamente. Figura retirada de (13).

Embora os resultados computacionais acima mencionados evidenciem a importância de dinâmicas particulares no processamento de informação, a diferença entre resolver as equações lentas e usar os valores pré-gravados correspondem a pequenas perturbações nos valores da condutância em um dado instante. Considerando que os modelos computacionais não estão normalmente sujeitos à ruído e não expressam toda a complexidade das células biológicas, nos perguntamos se tal mecanismo seria de fato relevante para a transmissão de informação entre neurônios. De forma a acessar experimentalmente o efeito da dinâmica de correntes específicas interagindo com a célula como um todo, desenvolvemos o protocolo que chamamos "Dissecação dinâmica em tempo real" descrito a seguir. 


\subsubsection{Dynamic Clamp adaptado}

Uma forma experimental de acessar o papel da dinâmica de uma determinada corrente iônica, levando em conta a sua interação com as demais e com o ambiente celular, é simular esta corrente através de dynamic clamp. Idealmente, a célula utilizada não deve conter a condutância a ser simulada de forma que o experimentador tenha controle sobre os parâmetros utilizados. Durante esses experimentos, o valor da condutância evolui dinamicamente de acordo com o cenário celular. Para isolar apenas o efeito da dinâmica de uma condutância, adaptamos o protocolo de dynamic clamp para realizar o seguinte ciclo (esquematizado na figura 10):

1. Através de uma rotina de dynamic clamp, adiciona-se à célula uma condutância do tipo Hodgkin-Huxley e uma corrente senoidal por um determinado intervalo de tempo, no qual a célula não recebe estímulos artificiais. Durante esse ciclo, os valores da condutância dinamicamente gerados e os da corrente do gerador são gravados em função do tempo em uma tabela, de forma que mantenham a relação de fase entre si.

2. O programa simula novamente a condutância do tipo Hodgkin-Huxley e adiciona a corrente senoidal lida no gerador, enquanto a célula recebe um estímulo artificial. Este consiste numa série temporal de bursts com distribuição aleatória de ISIs e é aplicado à célula através de uma sinapse química inibitória, simulada em tempo real pelo dynamic clamp. Chamaremos esta etapa de ciclo dinâmico.

3. O programa repete o passo anterior, porém substituindo a condutância lenta dinâmica pelos valores previamente gravados em tabela. Neste ciclo, dizemos que a dinâmica da condutância está "congelada", uma vez que não pode responder às perturbações do estímulo. 


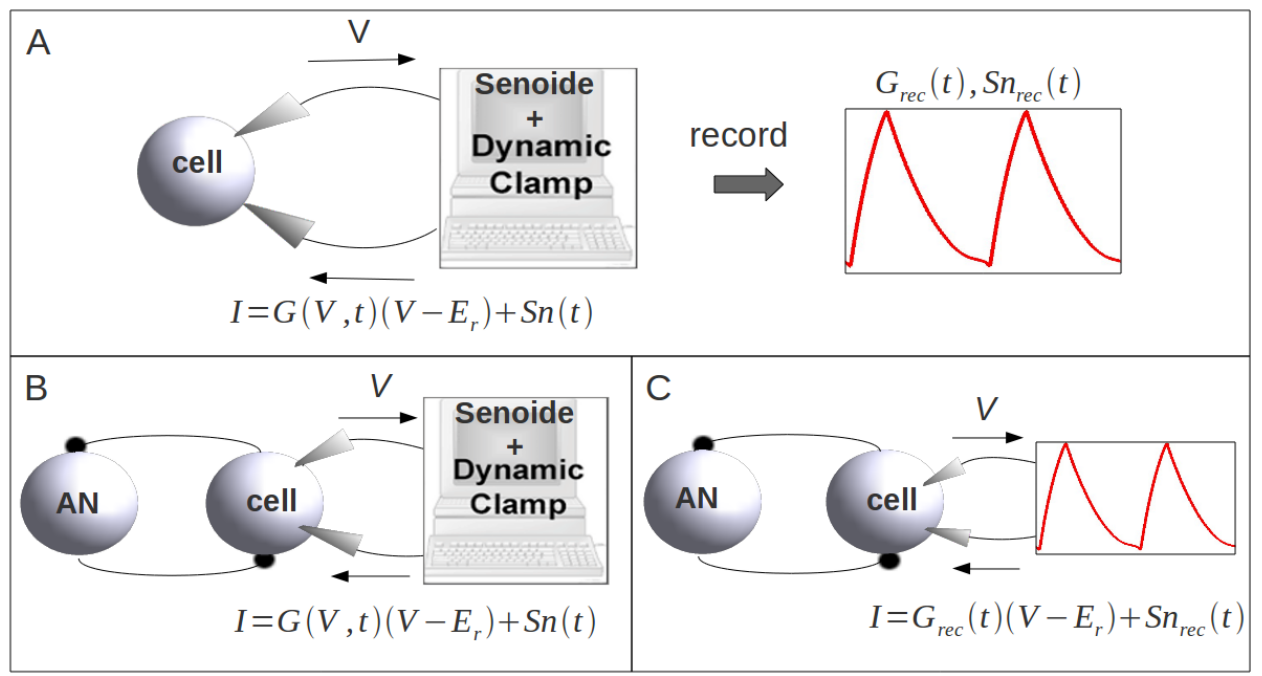

Figura 10 - Esquema de um experimento típico de dissecação dinâmica usando o dynamic clamp adaptado. A O dynamic clamp adiciona à célula uma condutância lenta do tipo Hodgkin-Huxley $(G(V, t))$ e uma corrente senoidal lida de um gerador de sinais em tempo real $(S n(t))$. Durante este ciclo os valores da condutância e da senóide são gravados em função do tempo em um arquivo, de forma a manterem a relação de fase entre si. B Faz-se um protocolo de dynamic clamp enquanto o neurônio recebe um estímulo artificial em forma de sinapse inibitória. C Repete-se o estímulo do ciclo anterior, porém utilizando os valores previamente gravados da condutância, $G_{r e c}$, e da senóide, $S n_{r e c}$. Note que o estímulo apresentado à célula pode alterar a evolução dinâmica da variável de ativação da condutância em $\mathbf{B}$ (condutância dinâmica), mas não em C (condutância congelada).

Em geral, a condutância é gerada por cinco minutos. Inicia-se então o experimento e o dynamic clamp alterna entre os passos 2 e 3 a cada cinco minutos por pelo menos uma hora. O programa pode gerar simultaneamente até quatro condutâncias iônicas diferentes, duas sinapses químicas e duas elétricas. Os sinais ajustados no gerador de corrente são lidos pelo programa e podem ser ligados/desligados em tempo real. A figura 11 mostra a interface gráfica do programa. Nos dois casos, séries temporais contendo os potenciais de membrana dos neurônios artificial e biológico e a corrente total injetada na célula são gravadas no computador de aquisição para posterior análise. Além disso, gravamos uma variável binária que indica qual ciclo, normal (passo 2) ou com condutância congelada (passo 3), está sendo gerado, o que permite separarmos as séries temporais para análise. 


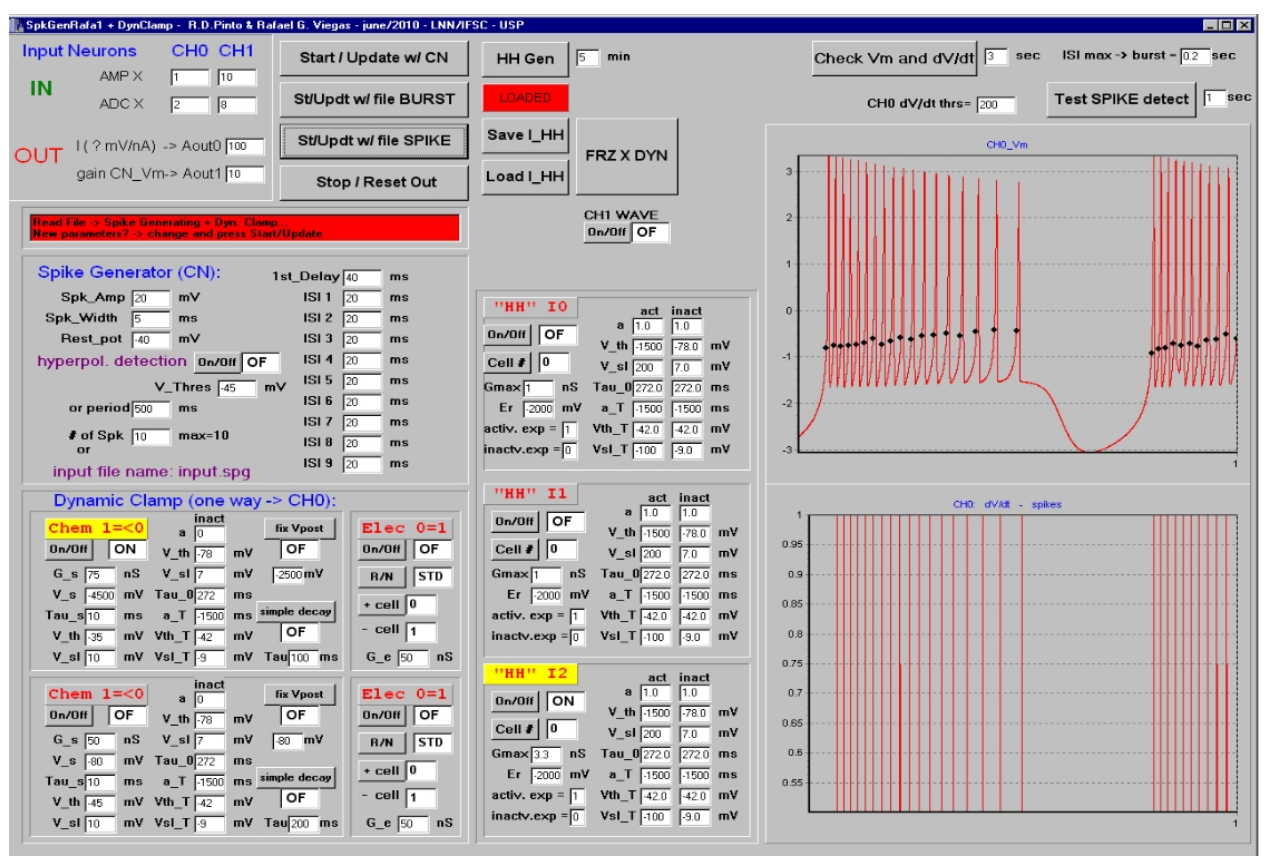

Figura 11 - Interface gráfica do dynamic clamp adaptado. O programa permite simular simultaneamente quatro sinapses, sendo duas químicas e duas elétricas. Além disso, pode-se adicionar até três condutâncias do tipo Hodgkin-Huxley e uma corrente de um gerador de sinais ( $W A V E O N / O F F$ ). Os gráficos mostram amostras do potencial de membrana e sua derivada, usados para definir o limiar de detecção de spikes.

\subsubsection{Dissecação dinâmica no $C P G$ gástrico}

Para aplicarmos o método acima descrito, escolhemos células do CPG gástrico do siri que não apresentam comportamento em bursts. Normalmente, estas células estão quiescentes ou disparam tonicamente. A injeção de uma pequena quantidade de corrente DC (tipicamente da ordem de 1 a 5 nA) é utilizada para verificar se o soma do neurônio é excitável e se possui ou não atividade lenta. Normalmente, as células gástricas apresentam uma grande quantidade de potenciais pós-sinápticos excitatórios (EPSPs) e respondem tonicamente à injeção de corrente constante.

De forma a obter séries mais estáveis e facilitar a inserção da corrente tipo HodgkinHuxley, injetamos uma corrente senoidal tipicamente com $1 \mathrm{~Hz}$ e amplitude da ordem de 1 a 2 nA. Tal corrente simula a presença de uma célula marca-passo ligada através de 
sinapse elétrica à célula em estudo. Uma vez que a mesma senóide é apresentada nas duas etapas (dinâmica e congelada) e devido à periodicidade, este sinal não interfere na análise final.

O modelo utilizado para se calcular a condutância lenta é baseado na corrente tipo $\mathrm{H}$ (18-19), que é ativa apenas na fase hiperpolarizada e está relacionada à inicialização dos bursts. Esta corrente foi inicialmente escolhida por ser mais simples, não dependendo da concentração intracelular de cálcio. Como os bursts que acontecem nas células gástricas possuem uma amplitude bem menor que nas células originais para as quais os modelos foram ajustados, as variáveis dinâmicas devem ser reescaladas de forma a produzir o comportamento desejado (ver Apêndice A). 


\section{$4 \quad$ Resultados}

\subsection{Introduzindo condutâncias lentas em células do $S T G$}

Mostraremos nesta seção os resultados referentes à introdução, via dynamic clamp, de condutâncias iônicas lentas nas células do STG. Para ter controle dos modelos utilizados, ajustamos o offset do amplificador intracelular para manter o potencial de repouso das células em $V_{m}=-60 m V$. Os parâmetros da condutância lenta e da senóide são ajustados de forma a obter bursts com a maior variabilidade possível no número de spikes e distribuição de ISIs. Os valores finais utilizados nos experimento são mostrados no Apêndice A. Embora ajustemos o modelo a cada experimento, sempre garantimos que a condutância lenta seja ativa na parte hiperpolarizada da rajada, sendo este o comportamento característico da condutância tipo H. Na Figura 12 mostramos a evolução dinâmica da condutância superposta ao potencial de membrana da célula.

Na Figura 13 mostramos um trecho da série do potencial de membrana no estado que chamamos de "repouso". Neste estado, o neurônio não recebe nenhum estímulo artificial. É durante esta etapa que salvamos os valores de condutância gerados para serem posteriormente utilizados. Mostramos no traço inferior desta figura a corrente total injetada na célula. É importante notar que as rajadas exibem certa variabilidade no número e distribuição dos ISIs.

As séries temporais de um experimento típico de dissecação dinâmica são mostradas na Figura 14. Os parâmetros do neurônio artificial são ajustados a cada experimento. Ajustamos também o potencial de reversão e a condutância máxima da sinapse química, 


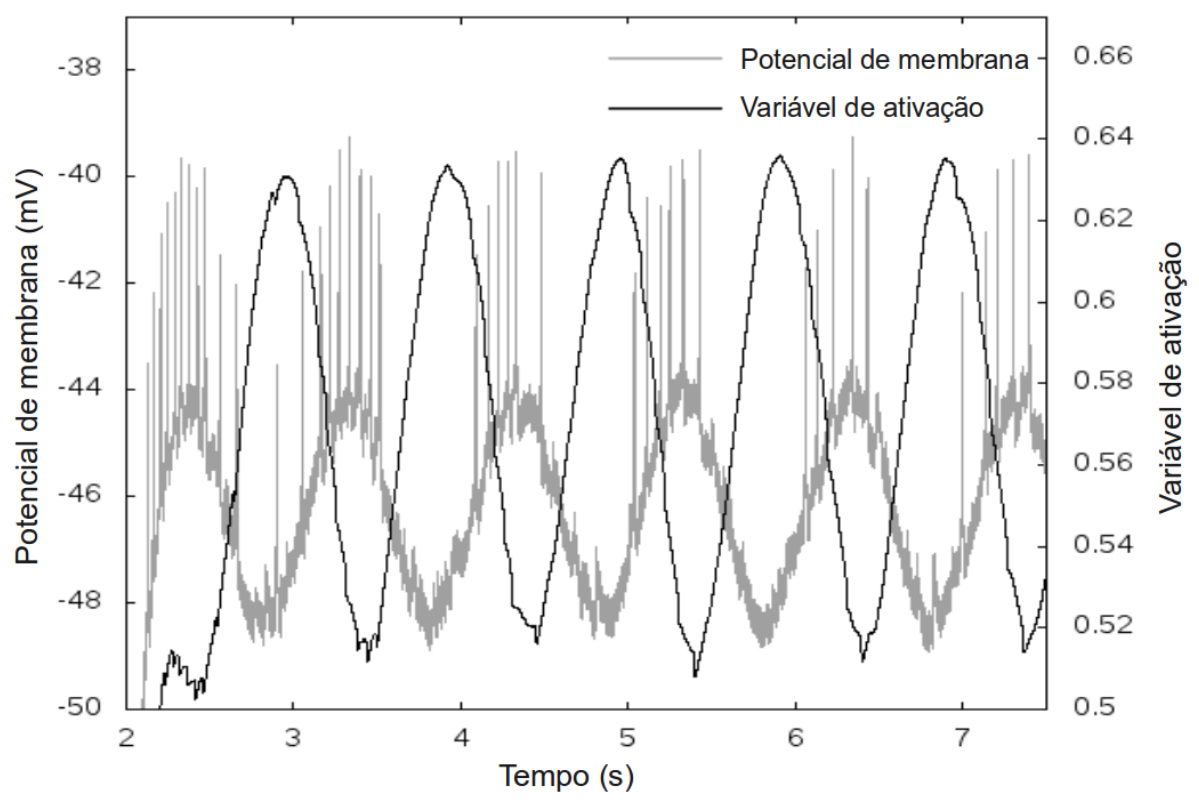

Figura 12 - Evolução dinâmica da variável de ativação da condutância artificial. A escala à esquerda corresponde ao potencial de membrana e à direita à variável de ativação da condutância tipo H. Série adquirida de célula gástrica do $S T G$ com adição da condutância $\mathrm{H}$ e de uma senóide de $1.5 n A$ de amplitude. A sobreposição com o potencial de membrana mostra que a condutância é ativada na fase hiperpolarizada.

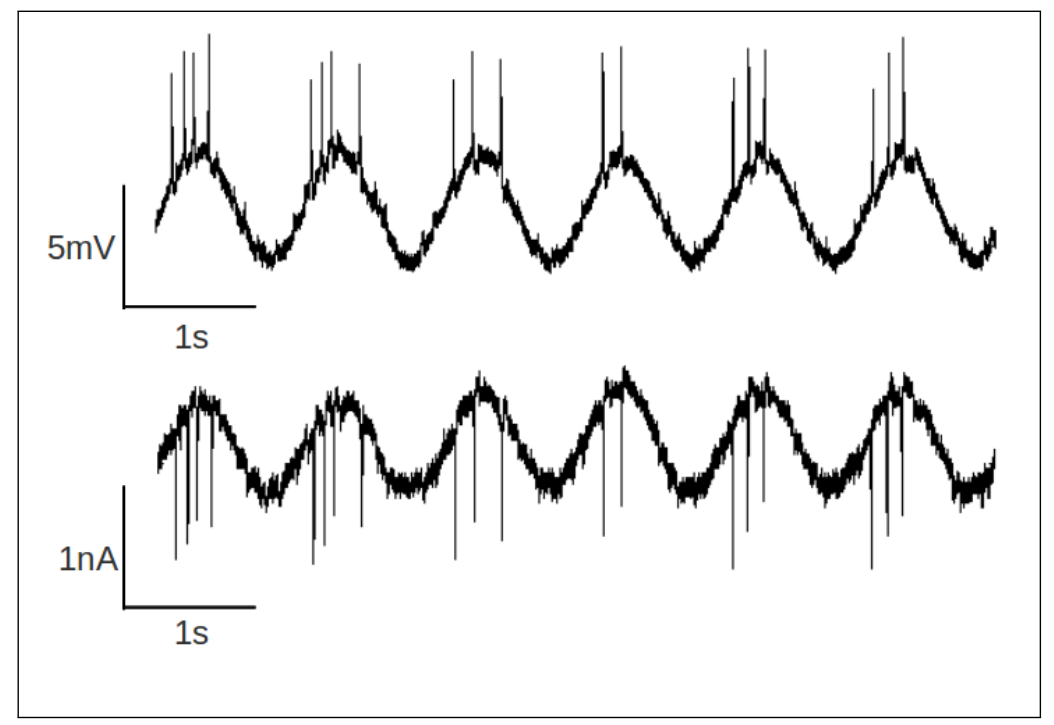

Figura 13 - Potencial de membrana e corrente total injetada. Neste caso, usamos uma célula gástrica em estado quiescente e adicionamos a condutância $\mathrm{H}$ e uma senóide de $1 \mathrm{~Hz}$ e $1.5 n A$ de amplitude.

de forma a produzir potenciais pós-sinápticos inibitórios (IPSPs) cujas intensidades sejam, pelo menos, da ordem dos estímulos naturais observados na célula. A Figura $14 a$ foi obtida 
durante o ciclo normal, enquanto a Figura $14 b$ foi obtida durante o ciclo com dinâmica congelada. Note que há variabilidade nos dois casos e a diferença entre as duas séries não é trivial.

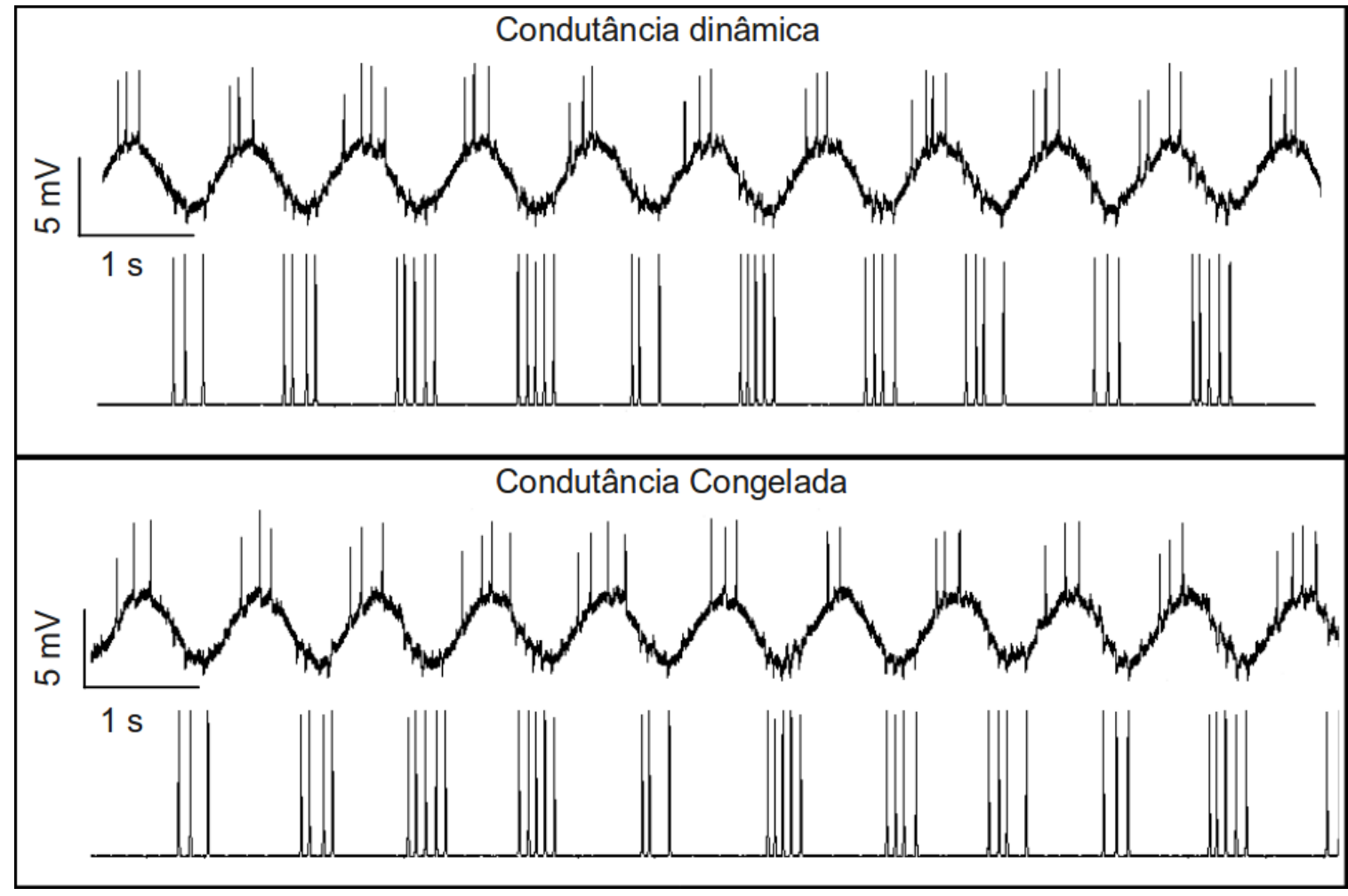

Figura 14 - Séries temporais de um experimento típico de dissecação dinâmica. A Condutância dinâmica. B Condutância congelada. Em ambas as Figuras, o traço de cima corresponde ao neurônio biológico e o de baixo ao neurônio artificial. Para cada disparo do neurônio artificial nota-se um pequeno potencial pós-sináptico inibitório no neurônio biológico.

\subsection{Análise de dados com Teoria da Informação}

Nesta seção, mostraremos a análise, via teoria da informação, dos dados obtidos em dois experimentos que chamaremos I e II. Estes experimentos foram realizados com dife- 
rentes células não identificadas, sendo necessário o uso de condutâncias lentas ligeiramente distintas para produzir bursts com alta variabilidade. As séries temporais foram adquiridas por pelo menos uma hora, resultando em cerca de 2000 pares estímulo-resposta para cada ciclo. Os parâmetros para condutância lenta e sinapse artificial são mostrados no Apêndice A.

Para aplicar a teoria da informação, como discutido na seção 2.5, devemos primeiro escolher o tamanho inicial dos bins e o tamanho, em bits, das palavras. Os bins são inicialmente escolhidos para que cada um contenha cerca de dois pontos experimentais e $\Delta T \sim 1 \mathrm{~ms}$. Para escolher o tamanho da palavra, calculamos a entropia máxima por posição no burst para palavras com valores crescentes de bits. Nota-se que os valores máximos de entropia aumentam à medida que aumentamos o tamanho das palavras, o que é intuitivo. No entanto, se definirmos a taxa informacional como sendo o valor máximo da entropia naquela posição dividido pelo tamanho da palavra, vemos que esta grandeza possui um pico, sendo baixa ou constante para palavras grandes. Deste modo, escolhemos o tamanho de palavra que maximiza a taxa informacional, garantindo que a palavra codifica a maior variabilidade em relação a sua extensão.

Na Figura 15 mostramos os gráficos de taxa informacional para os neurônios artificial e biológico para o caso de condutância dinâmica, para condutância congelada obtém-se resultado similar. No eixo $x$, mostramos a posição no burst que endereça o início da palavra e no eixo y o número de bits. O valor da taxa é dado de acordo com o código de cores. Os espaços brancos ocorrem quando o final da rajada é atingido, ou seja, quando a janela contendo a palavra não pode mais ser deslocada e o valor máximo de entropia ainda não foi atingido. Temos que, com exceção de alguns picos devidos a efeitos de bordas, os máximos ocorrem para palavras com poucos bits, o que é esperado intuitivamente uma vez que temos poucos eventos por rajada. A maior quantidade de picos, considerando ambos os neurônios simultaneamente, ocorre quando adotamos palavras de 2 bits.

Uma vez que fixamos o número de bits da palavra, seu tamanho em unidades de tempo pode ainda variar de acordo com a posição no burst. Isto porque o tamanho do bin 

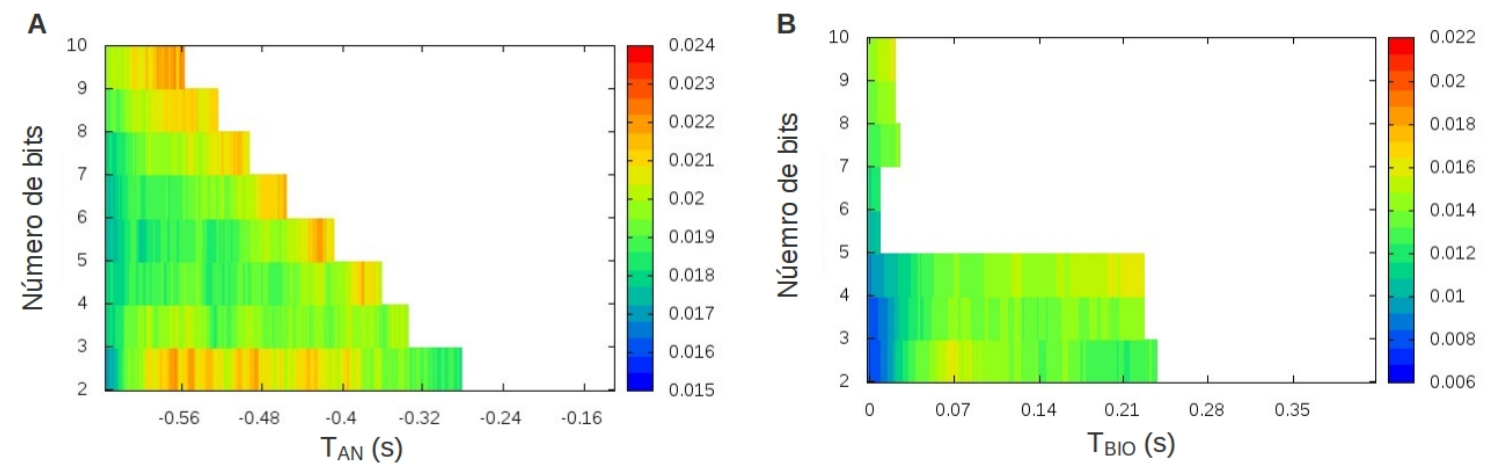

Figura 15 - Entropia por palavra para neurônios artificial e biológico. A Experimento IIcondutância dinâmica, dados para o neurônio artificial. B Experimento IIcondutância dinâmica, dados para o neurônio biológico. No eixo $x$, mostramos a posição em segundos no burst que endereça o início da palavra e no eixo $y$ o número de bits. O valor máximo da entropia por tamanho da palavra é mostrado de acordo com o código de cores. O maior número de picos, considerando ambos os neurônios simultaneamente, ocorre para palavras de 2 bits.

é escolhido de forma a maximizar a entropia em cada posição dentro do burst. A Figura 16 mostra a variação do tamanho normalizado, extensão da palavra dividida pela extensão total da distribuição de spikes, das palavras ao longo do burst para o experimento II comportamentos similares são obtidos no experimento I. As figuras à esquerda são obtidas do ciclo dinâmico e as figuras à direita são obtidas no ciclo com dinâmica congelada. O tamanho médio das palavras é $23 \%$ para o neurônio artificial e cerca de $36 \%$ para o neurônio biológico. Notamos que não há diferenças relevantes entre os dois ciclos e que o comportamento qualitativo das curvas é semelhante para os neurônios artificial e biológico.

Nas Figuras 17 e 18 mostramos o valor máximo de entropia por posição no burst para os experimentos I e II, respectivamente. Embora apresentemos o mesmo estímulo em ambos os ciclos, a interação deste com o neurônio biológico faz com que a distribuição efetiva do estímulo, em relação à resposta do neurônio biológico, seja ligeiramente diferente nos dois casos. Tal fato justifica as diferenças no valor de entropia entre as partes $A$ e $B$ das Figuras 17 e 18.

A partir de agora adotaremos a seguinte convenção para as Figuras. As figuras à esquerda correspondem a experimentos com a condutância lenta dinâmica e as à direita se 

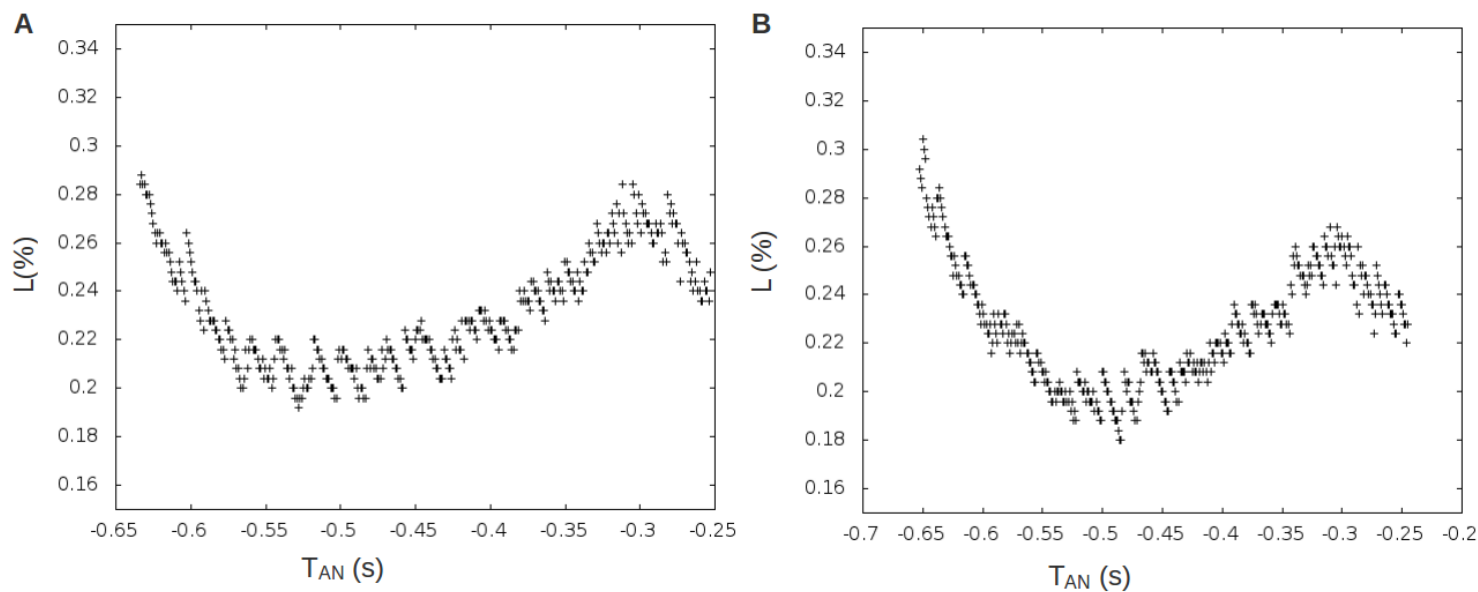

C

D
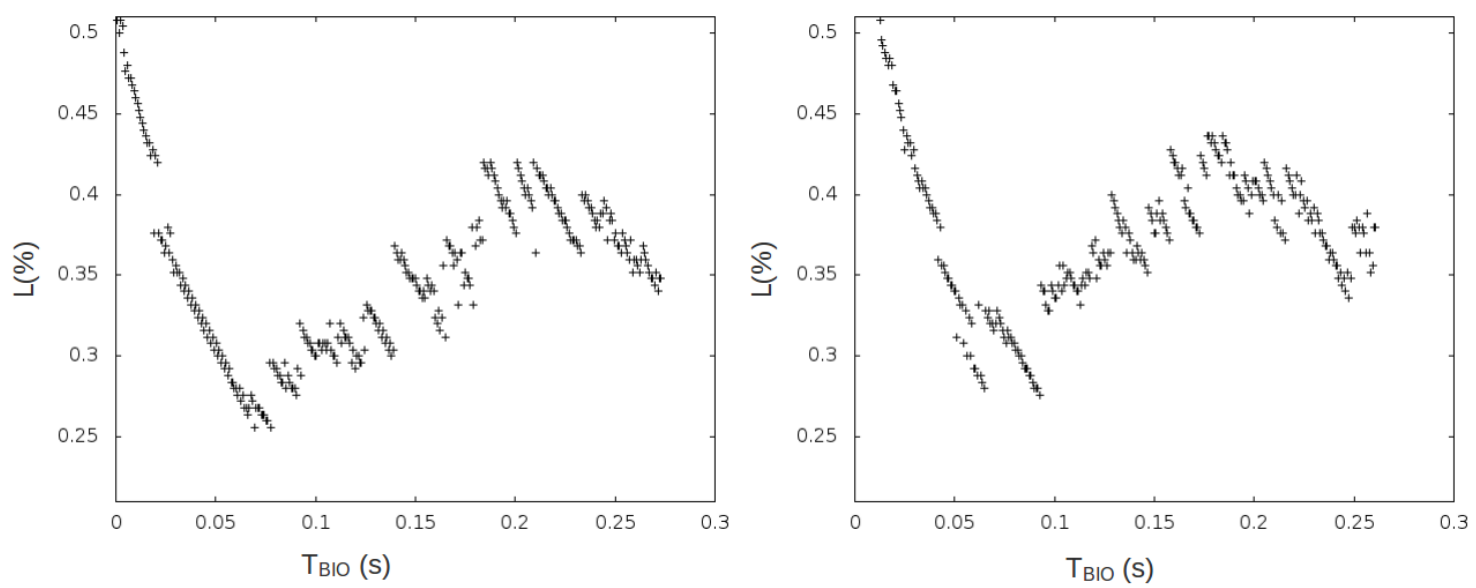

Figura 16 - Tamanho das palavras que maximiza a entropia por posição dentro do burst para o experimento II. Mostramos no eixo $x$ a posição em segundos do início de cada palavra e no eixo y o tamanho de cada palavra normalizado pela duração máxima do burst. A Condutância dinâmica, neurônio artificial. B Condutância congelada, neurônio artificial. C Condutância dinâmica, neurônio biológico. D Condutância congelada, neurônio biológico. Notamos que o tamanho das palavras varia lentamente ao longo do burst e que não há diferenças significativas entre os ciclos com condutância dinâmica e congelada.

referem aos experimentos com a condutância congelada. Na primeira linha, mostraremos resultados do experimento I e, na segunda, os resultados do experimento II. Para um mesmo experimento, os limites das distribuições - e portanto os eixos das figuras - não são exatamente iguais para os casos dinâmico e congelado devido à interação dinâmica entre os neurônios artificial e biológico. Desta forma, a comparação entre os gráficos dos ciclos dinâmico e congelado deve ser mais qualitativa do que estritamente quantitativa, analisando as posições relativas dos picos no burst. 

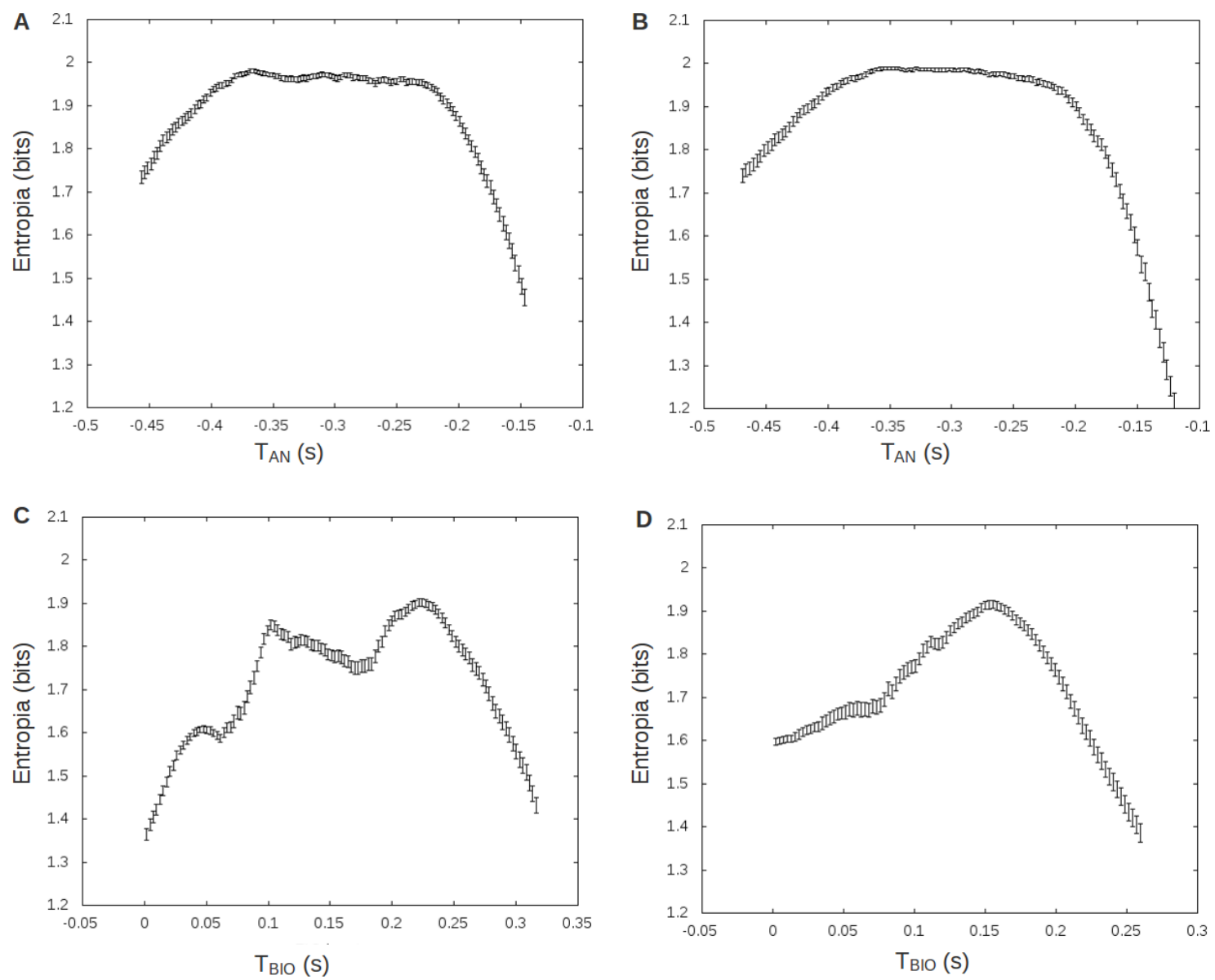

Figura 17 - Entropia por posição para experimento I. No eixo $x$ indicamos a posição de início das palavras utilizadas para calcular a entropia e no eixo $y$ o valor da entropia em bits. A Condutância dinâmica, neurônio artificial. B Condutância congelada, neurônio artificial. C Condutância dinâmica, neurônio biológico. D Condutância congelada, neurônio biológico. Note que a entropia é uma curva suave, variando lentamente ao longo do burst.

Na Figura 19 mostramos o valor de IMM entre os neurônios biológico e artificial. Os picos neste gráficos mostram quais partes das rajadas de estímulo e resposta estão mais correlacionadas. Vemos que a informação contida no estímulo é codificada de maneira não homogênea no burst de resposta, formando "ilhas" que se destacam do valor médio. Para o experimento I, há um pico de IMM do início do estímulo para o início da resposta (Figura 19A) altamente dependente da dinâmica da condutância lenta, uma vez que é insignificante para o caso de dinâmica congelada (Figura 19B). Para o experimento II, há quatros picos de informação entre os inícios e finais do estimulo e resposta, sendo mais evidente o pico do final do estímulo para o final da resposta. Este pico mais evidente é também resultante 

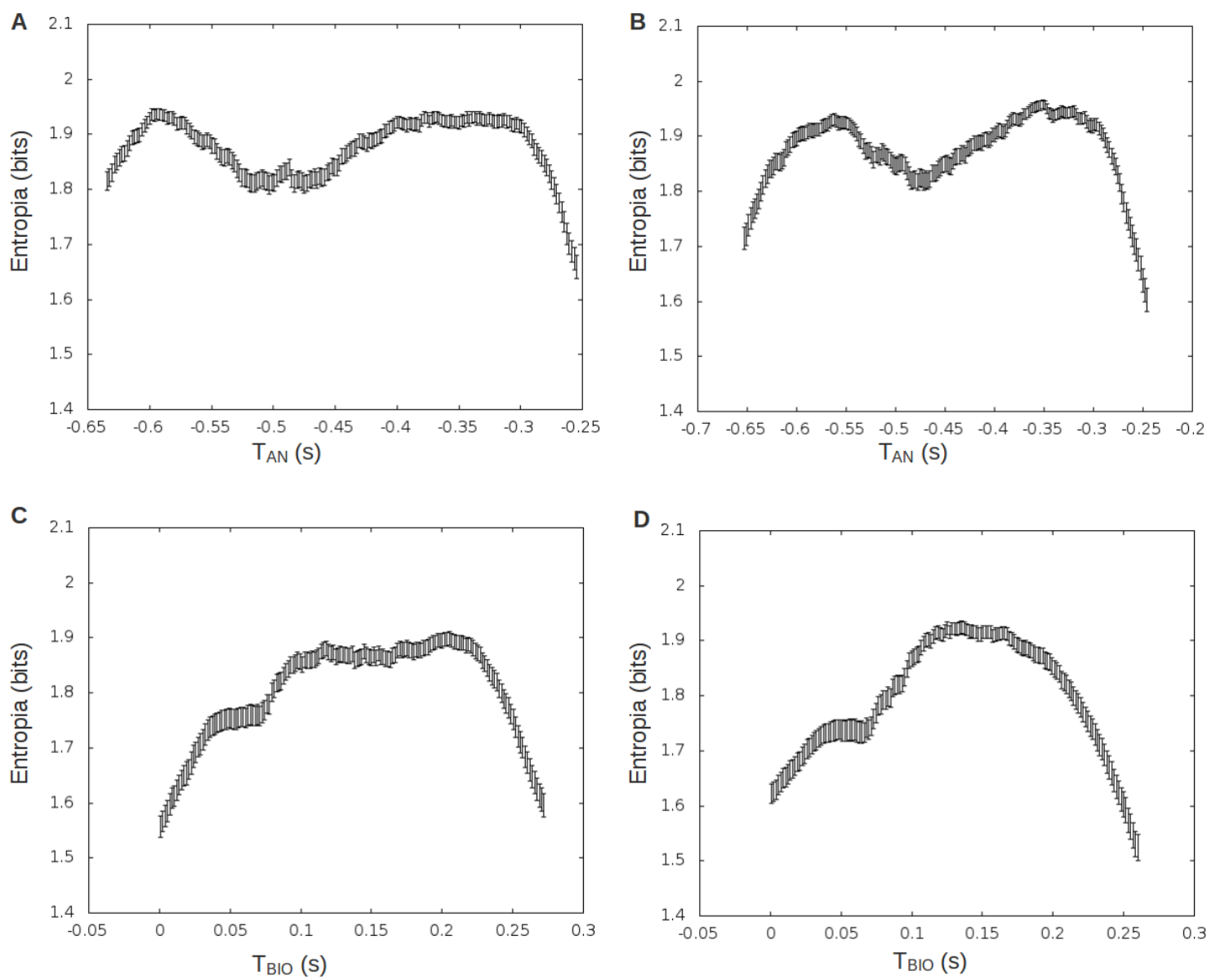

Figura 18 - Entropia por posição para experimento II. No eixo $x$ indicamos a posição de início das palavras utilizadas para calcular a entropia e no eixo $y$ o valor da entropia em bits. A Condutância dinâmica, neurônio artificial. B Condutância congelada, neurônio artificial. C Condutância dinâmica, neurônio biológico. D Condutância congelada, neurônio biológico. Note que a entropia é uma curva suave, variando lentamente ao longo do burst.

da dinâmica da condutância lenta como pode ser observado comparando-se as partes $C$ e $D$ da Figura 19. Discutiremos as implicações deste resultado mais a frente.

Para analisar os efeitos casuais das distribuições, mostramos na Figura 20 o valor médio de IMM média obtido analisando 15 conjuntos de dados embaralhados, isto é, mantendo a resposta e escolhendo uma nova pergunta aleatoriamente. Neste caso, temos as mesmas distribuições estatísticas de estímulo e resposta, mas quebramos a relação de causalidade entre elas. Os valores de $I M M_{\text {surr }}$ encontrados são aproximadamente constantes, com algumas pequenas ilhas espalhadas pela matriz e não apresentam diferenças significativas para as condutâncias dinâmica e congelada. Para o experimento I, Figuras 


$$
\text { A }
$$
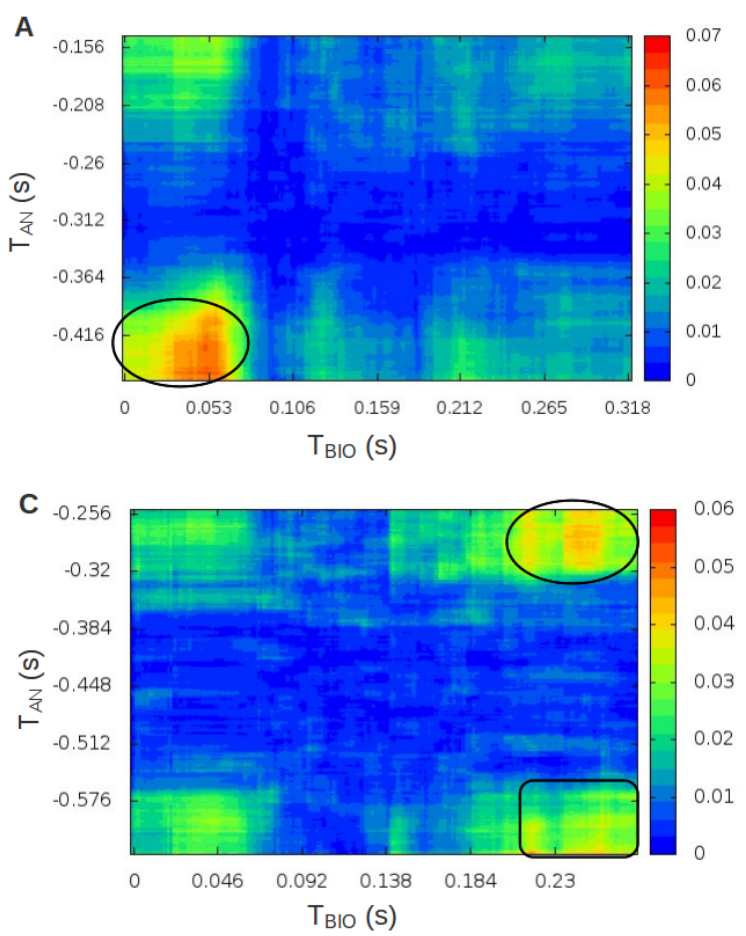

B
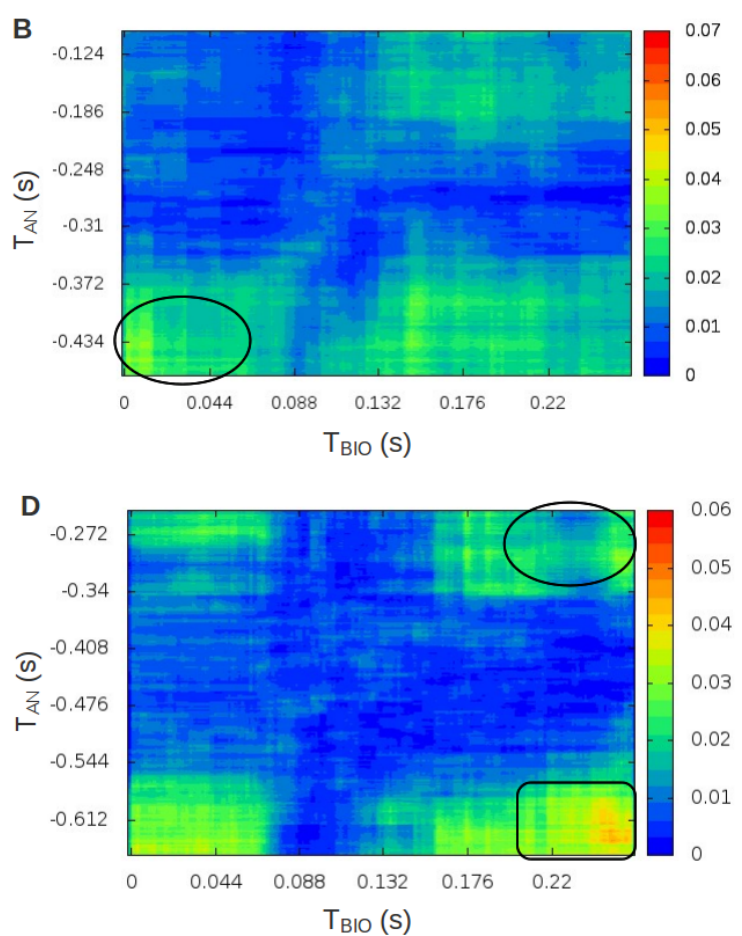

Figura 19 - Informação Mútua Média. No eixo $y$ e $x$, mostramos a posição no burst que endereça o início das palavras de estímulo e resposta, respectivamente. O valor de IMM é dado em bits de acordo com o código de cores expresso na barra lateral. A Experimento I, condutância dinâmica. B Experimento I, condutância congelada. Há um pico de IMM (região circulada) do início do estímulo para o início da resposta apenas para o ciclo com condutância dinâmica. C Experimento II, condutância dinâmica. D Experimento II, condutância congelada. O pico de IMM (região circulada) entre o final do estímulo e da resposta quase desaparece para o ciclo com condutância congelada.

$20 A$ e $20 B$, o valor dos picos são onze vezes menores que os encontrados para a série original, enquanto para o experimento II, Figuras $20 C$ e $20 D$, são seis vezes menores. É importante notar que os mesmos métodos de análise são aplicados aos conjuntos embaralhados e originais. Assim, vemos que as ilhas de informação mostradas na Figura 19 são de fatos oriundas da causalidade da série e não de efeitos espúrios do método ou das distribuições.

Apresentamos na Figura 21 os gráficos de IMM relativa, que combina os resultados anteriores, fornecendo uma forma mais direta de analisar os dados. Como comportamento geral, vemos que de fato os picos de informação mais relevantes (indicados por círculos) presentes no caso dinâmico desaparecem quase completamente no caso congelado. Os 

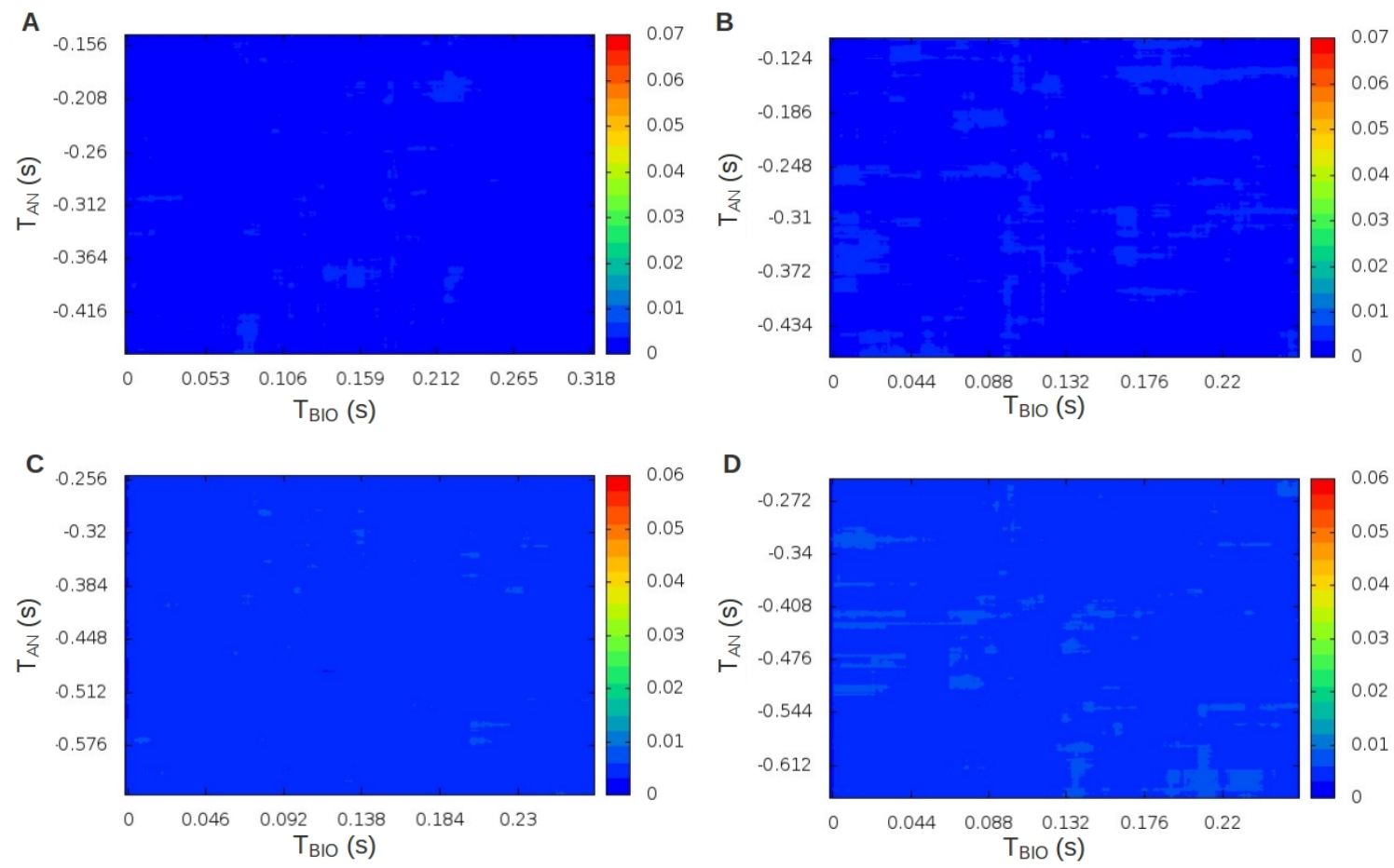

Figura 20 - Informação Mútua Média para dados de surrogates. Dados obtidos de 15 novos conjuntos, nos quais mantemos a série de bursts de resposta intacta e escolhemos aleatoriamente novos bursts de estímulo. As Figuras mostram os valores de IMM em bits obtidos aplicando-se o mesmo protocolo de análise para série original. A Experimento I, condutância dinâmica. B Experimento I, condutância congelada. C Experimento II, condutância dinâmica. D Experimento II, condutância congelada. Observamos que não há formação de picos e nem diferenças entre os casos com condutância dinâmica e congelada.

valores de $I M M_{\text {rel }}$ indicam a fração da variabilidade do burst de resposta dedicada a codificar o estímulo. Assim, considerando os picos, temos que 4,5\%, para o experimento I, e 2,5\%, para o experimento II, da variabilidade da resposta são dedicados à codificação do estímulo. Este valores podem parecer baixos, mas devemos lembrar que os experimentos foram realizados em células no circuito intacto e interagindo com os demais neurônios da rede. Além disso, o estímulo apresentado, assim como a corrente lenta, não possui caráter naturalístico para as células do $S T G$ gástrico. Desta forma, consideramos que os valores encontrados são razoáveis, uma vez que o caráter artificial dos experimentos dificilmente admite resultados falsos positivos.

Os dois picos inferiores nas Figuras $21 C$ e $21 D$ - principalmente do começo do estímulo para o final da resposta (indicado por um retângulo) - são intensificados para o ciclo com 
condutância congelada. No entanto, na Figura 19 não vemos uma diferença significativa entre os dois casos: os picos de IMM nestas regiões são apenas ligeiramente distorcidos, mantendo uma estrutura semelhante para os casos dinâmico e congelado. Por outro lado, analisando o comportamento da entropia do neurônio biológico para o experimento II, Figuras $18 C$ e $18 D$, vemos que esta é maior no final do burst para o ciclo dinâmico, mantendo um patamar elevado até aproximadamente 0,23s. Desta forma, embora a quantidade de IMM local seja semelhante para os dois ciclos, a menor variabilidade da resposta nesta região durante o ciclo com condutância congelada provoca o aumento observado no valor de $I M M_{\text {rel }}$. Acreditamos que estes picos sejam devidos a outras condutâncias presentes na célula e sejam apenas fracamente influenciados pela condutância lenta artificial.
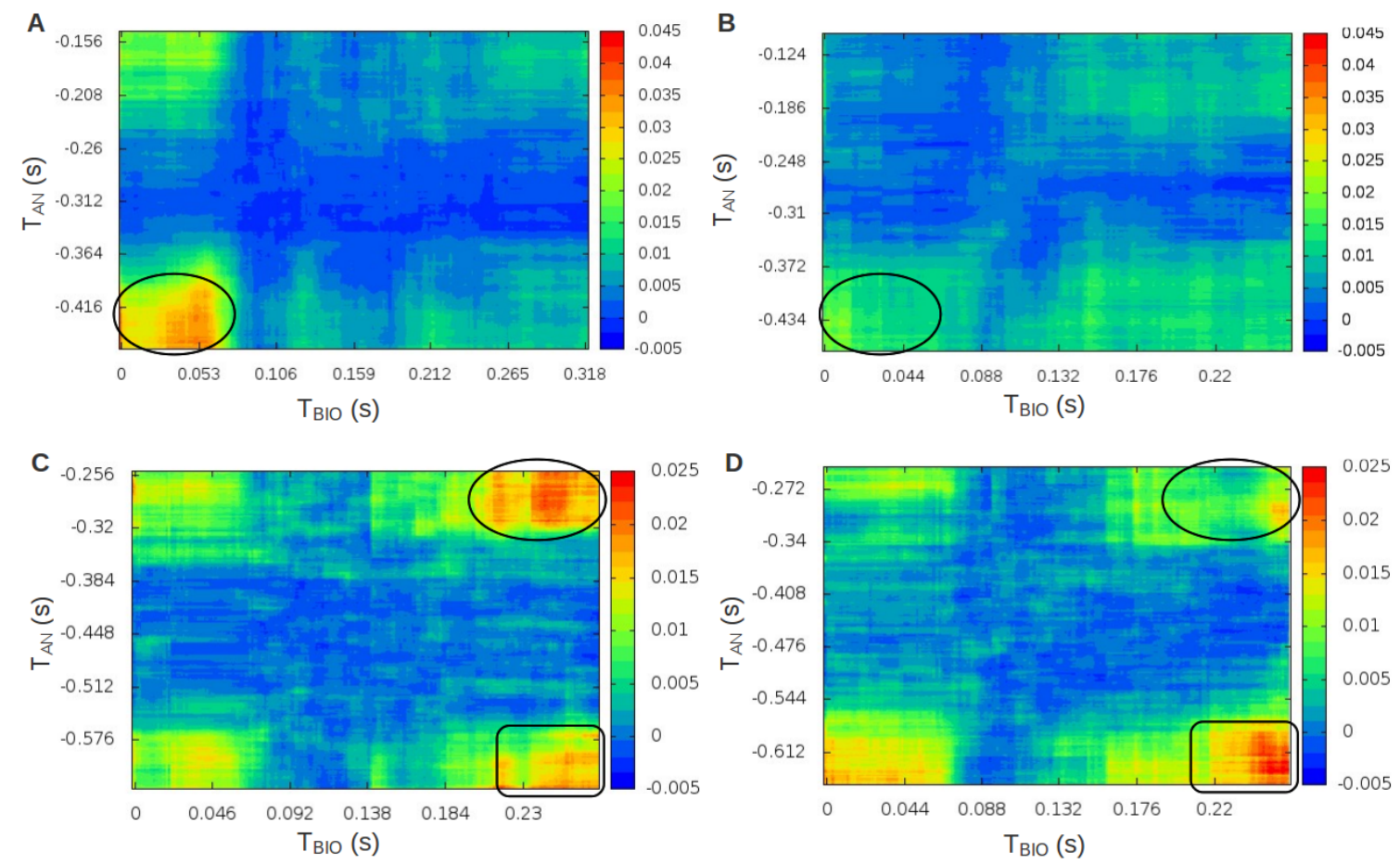

Figura 21 - Informação Mútua Média relativa. Os valores de $I M M_{r e l}$ são obtidos fazendo-se a diferença entre os valores de IMM dos dados originais e surrogates e dividindo pela entropia da resposta. A Experimento I, condutância dinâmica. B Experimento I, condutância congelada. Há picos do começo e do final do estímulo para o começo da resposta apenas para a condutância dinâmica (região circulada). C Experimento II, condutância dinâmica. D Experimento II, condutância congelada. Nota-se que o pico do final do estímulo para o final da resposta (região circulada) depende da condutância dinâmica, enquanto os picos do início do estímulo para o início e final (região entre o retângulo) da resposta são ligeiramente intensificados para a condutância congelada. 
Por fim, na Figura 22 mostramos um gráfico da significância,

$$
\operatorname{sig}=\frac{I M M-\langle I M M\rangle}{\sigma_{I M M}}
$$

sendo $\sigma_{I M M}$ desvio padrão. Os pontos que possuem significância alta correspondem às posições das ilhas de IMM. Para o experimento I, este picos estão a cerca de 50 desvios padrões em relação ao valor médio e, para o experimento II, o pico principal está a cerca de 40 desvios padrões da média.
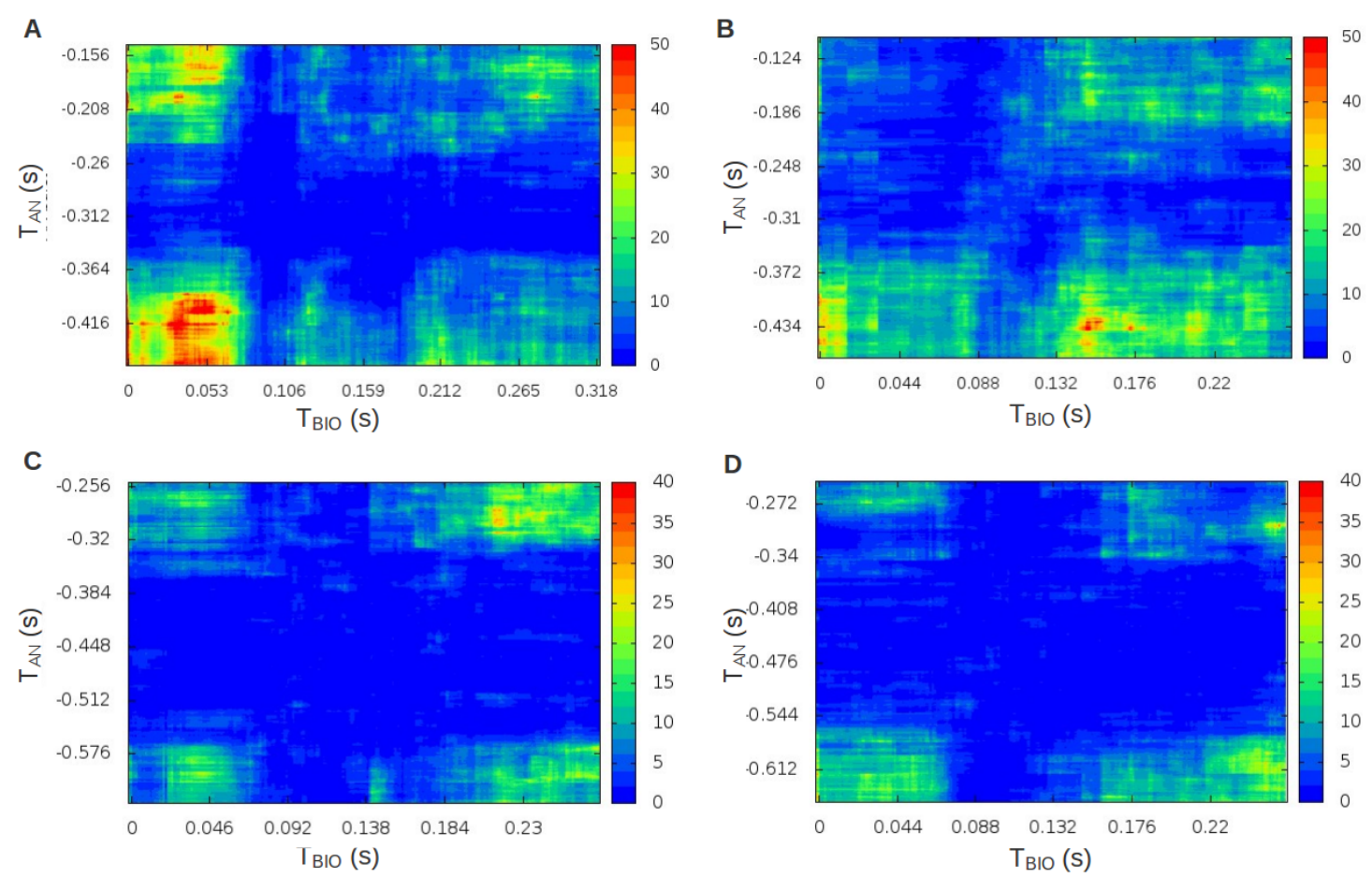

Figura 22 - Significância estatística para valores de IMM. A Experimento I, condutância dinâmica. B Experimento I, condutância congelada. C Experimento II, condutância dinâmica. D Experimento II, condutância congelada. Observamos que os picos de significância estão entre 40 e 50 desvios padrões de distância do valor médio e ocorrem nas mesmas posições dos picos de IMM dados na Figura 19.

Os experimentos I e II não são diretamente comparáveis, pois foram realizados em células diferentes, sendo inclusive necessário usar modelos de condutância e senóides diferentes. Isto explica as diferentes posições dos picos nos gráficos de IMM. No entanto, o que deve ser notado é que, muito embora tenhamos inserido uma corrente lenta artificial em uma célula pertencente à uma rede, a codificação dos estímulos artificiais ocorre de forma semelhante à encontrada no caso puramente biológico (Figura 9). Além disso, como 
indicado através de simulações numéricas (13), os picos de informação são dependentes da dinâmica da condutância lenta. Para elucidar completamente como este mecanismo ocorre seria necessário a realização de diversos experimentos e simulações numéricas explorando o espaço de parâmetros da condutância lenta, assim como testar outros modelos de condutância e as interações entre eles. Uma vez que as diferenças entre os ciclos normal e de dinâmica congelada são pequenas perturbações na variável de ativação da condutância lenta, outra questão igualmente importante seria entender e explorar o papel das propriedade estocásticas dos canais iônicos neste mecanismo, bem como sua robustez a ruídos externos, oriundos do meio biológico. Estas questões continuam em aberto e serão tratadas em projetos futuros. 


\section{Conclusões}

Implementamos um protocolo de dissecação dinâmica de condutâncias iônicas em tempo real para estudar a importância das condutâncias lentas na transmissão/codificação de informação em redes neurais biológicas e híbridas.

Nosso método foi baseado na adaptação de uma versão de dynamic clamp, um protocolo utilizado para interfacear em tempo real tecido nervoso vivo com modelos computacionais. A versão desenvolvida durante este projeto de mestrado é capaz de interagir com um neurônio biológico, gerar e salvar uma série temporal com os valores dinâmicos de uma dada condutância modelada matematicamente e introduzi-los posteriormente no neurônio biológico durante um ciclo em que este também recebe um estímulo vindo de um neurônio artificial. Comparando a resposta da célula biológica neste ciclo com sua resposta durante outro ciclo quase idêntico, mas no qual a condutância é integrada em tempo real, mostramos que é possível observar macroscopicamente os efeitos sutis da dinâmica do modelo, mesmo quando este interage com um ambiente celular realista.

Implementamos modelos inspirados nas condutâncias lentas do tipo $\mathrm{H}$ e realizamos experimentos com células do $C P G$ gástrico de siris azuis. Mostramos que estas células, que não apresentam atividade lenta in vitro, passam a disparar bursts com distribuições de spikes com alta entropia quando adicionamos a condutância lenta e uma corrente senoidal.

As séries temporais obtidas para o potencial de membrana do neurônio biológico em experimentos em que alternamos o tipo de condutância usada (dinâmica ou previamente armazenada) mostraram que as diferenças são muito sutis uma vez que devem-se apenas às pequenas perturbações que o neurônio artificial introduz indiretamente nas variáveis dinâmicas da condutância artificial, quando esta é integrada em tempo real.

Para evidenciar as diferenças entre os dois casos, foi utilizada uma ferramenta da Teoria da Informação adaptada para os neurônios que apresentam rajadas de spikes: cal- 
culamos a IMM local entre o neurônio artificial e o neurônio biológico ao longo de seus bursts. Os gráficos de IMM obtidos reproduziram qualitativamente o comportamento observado em neurônios biológicos do $C P G$ pilórico, com a formação de picos de informação entre partes específicas do estímulo e da resposta, mas apenas no caso da condutância artificial dinâmica.

Nosso protocolo de dissecação dinâmica nos permitiu validar experimentalmente os resultados obtidos anteriormente apenas em simulações computacionais e apontar a cinética das condutâncias lentas como fundamentais para permitir a codificação de informação em IBSPs em neurônios que apresentam rajadas. 


\section{REFERÊNCIAS}

1 HODGKIN, A. L.; HUXLEY, A. F. A quantitative description of membrane current and its application to conduction and excitation in nerve. Journal of Physiology, v. 117, n. 4 , p. 500-544, 1952.

2 MARDER, E. From biophysics to models of network function. Annual Review of Neuroscience, v. 21, n. 1, p. 25-45, 1998.

3 IZHIKEVICH, E. M. Dynamical Systems in Neuroscience: the geometry of excitability and bursting. Massachusetts: MIT Press, 2007. $441 \mathrm{p}$.

4 LATORRE, R.; RODRÍGUEZ, F.; VARONA, P. Neural signatures: multiple coding in spiking-bursting cells. Biological Cybernetics, v. 85, n. 2, p. 169-183, 2006.

5 SELVERSTON, A. I.; MOULINS, M. The crustacean stomatogastric system: a model for the study of central nervous systems. Berlim: Springer-Verlag, 1986. 338 p.

6 SELVERSTON, A. I. Invertebrate central pattern generator circuits. Philosophical Transactions of the Royal Society of London B : biological sciences, v. 365, n. 1551, p. 2329-2345, 2010.

7 HOOPER, S.; GUSCHLBAUER, C.; UCKERMANN, G. V.; BÜSCHGES, A. Different motor neuron spike pattern produce contractions with very similar rises in graded slow muscles. Journal of Neurophysiology, v. 97, n. 2, p. 1428 - 1444, 2007.

8 SZÜCS, A.; PINTO, R. D.; RABINOVICH, M. I.; ABARBANEL, H. D. I.; SELVERSTON, A. I. Synaptic modulation of the interspike interval signatures of bursting pyloric neurons. Journal of Neurophysiology, v. 89, n. 3, p. 1363 - 1377, 2003.

9 CAMPOS, D.; AGUIRRE, C.; SERRANO, E.; RODRIGUEZ, F. B.; POLAVIEJA, G. G.; VARONA, P. Temporal structure in the bursting activity of the leech heartbeat CPG neurons. Neurocomputing, v. 70, n. 10-12, p. 1792-1796, 2007.

10 RODRIGUES, L. B.; CARELLI, P. V.; PINTO, R. D. Single synapse information coding in bursting motor neurons. Submetido para publicação.

11 TURRIGIANO, G. G.; MARDER, E.; ABBOTT, L. F. Cellular short-term memory from a slow potassium conductance. Journal of Neurophysiology, v. 75, n. 2, p. 963-966, 1996. 
12 DELORD, B.; BARADUC, P.; COSTALAT, R.; BURNOD, Y.; GUIGON, E. A model study of cellular short-term memory produced by slowly inactivating potassium conductances. Journal of Computational Neuroscience, v. 8, n. 3, p. 251-273, 2000.

13 RODRIGUES, L. B.; MARIN, B.; PINTO, R. D. The role of specific ionic conductances in information coding in motor neurons. In: NEUROSCIENCE MEETING, 40., 2010. Abstracts... San Diego: Society for neuroscience, 2010. Disponível em: <http://www.abstractsonline.com/Plan/ViewAbstract.aspx?sKey=3a97d3fa54aa-4d1a-9ff0-adea159f3380\&cKey=2c3c3267-7dde-4d20-a016fac6f3215c4c\&mKey $=\{$ E5D5C83F-CE2D-4D71-9DD6-FC7231E090FB $\}>. \quad$ Acesso em: 12 jan. 2011.

14 PINTO, R. D.; ELSON, R. C.; SZÜCZ, A.; RABINOVICH, M. I.; SELVERSTON, A. I.; ABARBANEL, H. D. I. Extended dynamic clmap: controlling up to four neurons using a single desktop computer and interface. Journal of Neuroscience Methods, v. 108, n. 1, p. 39-48, 2001.

15 PRINZ, A.; ABBOTT, L. F.; MARDER, E. The dynamic clamp comes of age. Trends in Neurosciences, v. 27, n. 4, p. 218-224, 2004.

16 ZHAO, Y.; WANG, D. O.; MARTIN, K. C. Preparation of aplysia sensory-motor neuronal cell cultures. Journal of Visualized Experiments, n. 28, p. 7-9, 2009.

17 LYLES, V.; ZHAO, Y.; MARTIN, K. C. Synapse formation and mRNA localization in cultured aplysia neurons. Neuron, v. 49, n. 3, p. 349-356, 2006.

18 PRINZ, A.; BILIMORIA, C.; MARDER, E. Alternative to hand-tuning conductance-based models: construction and analysis of databases of model neurons. Journal of Neurophysiology, v. 90, n. 6, p. 3998-4015, 2003.

19 MCCORMICK, D.; PAPE, H. Properties of a hyperpolarization-activated cation current and its role in rhythmic oscillation in thalamic relay neurones. Journal of Physiology, v. 431, p. 291-318, 1990.

20 KANDEL, E. R.; SCHWARTZ, J. H.; JESSELL, T. M. Principles of Neural Science. 4. ed. New York: McGraw-Hill, 2000. 1414 p.

21 PURVES, D.; AUGUStine, G. J.; FitzPATRICK, D.; HALL, W. C.; LAMANTIA, A.; MCNAMARA, J. O.; WILLIANMS, S. M. (Ed.). Neuroscience. 4. ed. Massachusetts: Sinauer Associates, Inc., 2007. 857 p.

22 DAYAN, P.; ABBOT, L. F. Theoretical Neuroscience: computational and mathematical modeling of neural systems. Cambridge: MIT Press, 2005. 480 p. 
23 QUANTITATIVE MODELS OF THE ACTION POTENTIAL. In: WIKIPEDIA, the free encyclopedia. Florida: Wikimedia Foundation, 2011. Disponível em: <http://en.wikipedia.org/wiki/Quantitative_models_of_the_action_potential>. Acesso em: 12 jan. 2011.

24 CARElli, P. V.; REYES, M. B.; SARTORELI, J. C.; PINTO, R. D. Whole cell stochastic model reproduces the irregularities found in the membrane potential of bursting neurons. Journal of Neurophysiology, v. 94, n. 2, p. 1169-1179, 2005.

25 MULLONEY, M.; SELVERSTON, A. I. Organization of the stomatogastric ganglion of the spiny lobster. Journal of Comparative Physiology A: neuroethology, sensory, neural, and behavioral physiology, v. 91, n. 1, p. 33-51, 1974.

26 SELVERSTON, A. I. Stomatogastric ganglion. Scholarpedia, v. 3, n. 4, p. 1661, 2008. Disponível em: <http://www.scholarpedia.org/article/Stomatogastric_ganglion $>$. Acesso em: 17 jan. 2011.

27 SHARP, A. A.; O’NEIL, M. B.; ABBOTT, L. F.; MARDER, E. Dynamic clamp: computer-generated conductances in real neurons. Journal of Neurophysiology, v. 69, n. 3, p. $992-995,1993$.

28 DESTEXHE, A.; BAL, T. (Ed.). Dynamic-Clamp: from principles to applications. New York: Springer, 2009. 429 p.

29 SHANNON, C. E. A mathematical theory of communication. Bell Systems Technical Journal, v. 27, p. 379-423, 623-656, 1948.

30 RIEKE, F.; WARLAND, D.; STEVENINCK, R. R.; BIALEK, W. Spikes: exploring the neural code. Cambridge: MIT Press, 1999. 416 p.

31 BORST, A.; THEUNISSEN, F. E. Information theory and neural coding. Nature Neuroscience, v. 2, n. 11, p. 947-957, 1999.

32 TheIlER, J.; EUBANK, S.; LONGTIN, A.; GALDRIKIAN, B.; FARMER, J. D. Testing for nonlinearity in time series: the method of surrogate data. Physica D: nonlinear phenomena, v. 58, n. 1-4, p. 77-94, 1992.

33 DESTEXHE, A.; MAINEN, Z. F.; SEJNOWSKI, T. J. Syntesis of models for excitable membranes, synaptic transmission and neuromodulation using a common kinect formalism. Journal of Computational Neuroscience, v. 1, n. 3, p. 195-230, 1994. 


\section{Apêndice $A$}

\section{Parâmetros e equações adicionais}

\section{A.1 Condutância e sinapse artificiais}

A implementação de dynamic clamp utilizada como base neste trabalho foi inicialmente desenvolvida em 2001 (14). O programa é escrito em $C^{++}$e desenvolvido para um ambiente Windows. Detalhes sobre a implementação podem ser encontrados em (14).

A corrente a ser injetada em um neurônio pós-sináptico devido a uma sinapse química é calculada de acordo com um modelo cinético de liberação de neurotransmissores de primeira ordem (33):

$$
I_{\text {sin }}=G_{\text {sin }} \cdot S(t) \cdot h(t) \cdot\left(V_{\text {sin }}-V_{\text {pos }}\right)
$$

neste caso, $G_{\sin }$ é a condutância sináptica máxima, $S$ é uma variável de ativação, $h$ é uma variável de inativação incluída para simular depressão, $V_{\text {sin }}$ é o potencial de reversão da sinapse e $V_{\text {pos }}$ é o potencial instantâneo do neurônio pós-sináptico. Estas variáveis possuem o seguinte comportamento:

$$
\begin{gathered}
\left.\left(1-S_{\infty}\left(V_{\text {pre }}\right)\right) \tau_{s} \frac{d S(t)}{d t}=S_{\infty}\left(V_{\text {pre }}\right)-S(t)\right) \\
\tau_{h}\left(V_{\text {pre }}\right) \frac{d h(t)}{d t}=h_{\infty}\left(V_{\text {pre }}\right)-h(t) \\
S_{\infty}\left(V_{(p r e)}\right)=\left\{\begin{array}{lc}
\tanh \left(\frac{V_{\text {pre }}(t)-V_{\text {th }}}{V_{s l}}\right), & V_{\text {pre }}>V_{\text {th }} \\
0, & V_{\text {pre }}<V_{\text {th }}
\end{array}\right. \\
h_{\infty}\left(V_{\text {pre }}\right)=\frac{a_{h}}{1+\exp \left(\frac{V_{p r e}-V_{t h h}}{V_{s l h}}\right)}, \quad \tau_{h}\left(V_{\text {pre }}\right)=\tau_{0}-\frac{a_{T}}{1+\exp \left(\frac{V_{p r e}-V_{t h T}}{V_{s l T}}\right)}
\end{gathered}
$$

$S_{\infty}$ é o valor final da ativação, $h_{\infty}$ é a inativação final, $\tau_{h}$ é a constante temporal de

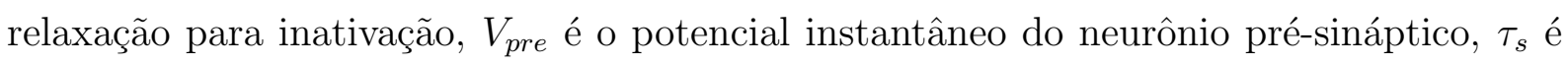


a constante temporal da sinapse, $V_{t h}$ é o potencial de limiar de ativação e $V_{s l}$ define a inclinação da curva de ativação para $S_{\infty}$. Por fim, $\tau_{0}, a_{T}, V_{t h T}, V_{t h h} V_{s l h}$ e $V_{s l T}$ definem as propriedades dinâmicas da inativação da sinapse.

Os parâmetros adotados em nossos experimentos foram escolhidos de forma a causar um potencial pós-sináptico semelhante aos experimentalmente observados nas células gástricas. Os valores destes parâmetros são mostrados na tabela 1.

Tabela 1 - Parâmetros da sinapse química artificial (ver equações (A.2) a (A.5)). Valores escolhidos de forma a produzir potenciais pós-sinápticos inibitórios $(I P S P s)$ da ordem dos observados no sistema intacto . Como utilizamos um modelo sem variável de inativação, os respectivos parâmetros não mostrados na tabela.

\begin{tabular}{ccc}
\hline & Exp. I & Exp. II \\
\hline$G_{s}(n S)$ & 90 & 120 \\
$V_{s}(m V)$ & -70 & -60 \\
$\tau_{s}$ & 10 & 10 \\
$V_{t h}(m V)$ & -35 & -35 \\
$V_{s l}(m V)$ & 10 & 10 \\
$a$ & 0 & 0 \\
\hline
\end{tabular}

As correntes de Hodgkin-Huxley são simuladas no dynamic clamp por meio das seguintes equações

$$
\begin{array}{r}
I_{H H}=G_{\max } m(t)\left(E_{r}-V(t)\right), \\
\tau_{m}(V) \frac{d m}{d t}=m_{\infty}(V)-m, \\
m_{\infty}=\frac{a}{1+\exp \left(\frac{V-V_{t h}}{V_{s} l}\right)}, \\
\tau_{m}=\tau_{0}-\frac{a_{T}}{1+\exp \left(\frac{V-V_{t h T}}{V_{s l T}}\right)} .
\end{array}
$$

Os parâmetros utilizados para simular a corrente do tipo $\mathrm{H}$ durante os experimentos I e II são mostrados na tabela 2. A tabela 3 mostra os parâmetros ajustados para as senóide em cada experimento. 
Tabela 2 - Parâmetros da condutância lenta tipo H utilizada nos experimentos (ver equações (A.7) a (A.9))

\begin{tabular}{ccc}
\hline & Exp. I & Exp. II \\
\hline$G_{\max }(n S)$ & 300 & 500 \\
$E_{r}(m V)$ & -42 & -30 \\
$a$ & 1 & 1 \\
$V_{t h}(m V)$ & -57 & -43 \\
$V_{s l}(m V)$ & 2 & 6 \\
$\tau_{0}(m s)$ & 0 & 0 \\
$a_{T}(m s)$ & -400 & -1000 \\
$V_{t h T}(m V)$ & -70 & -65 \\
$V_{s l T}(m V)$ & 2.5 & 12 \\
\hline
\end{tabular}

Tabela 3 - Parâmetros utilizados na senóide. Assim como para condutância, estes parâmetros são escolhidos de forma que os bursts resultantes tenham a maior variabilidade no número de spikes e distribuição de ISIs

\begin{tabular}{lcc}
\hline & Exp. I & Exp. II \\
\hline Amplitude (nA) & 1.5 & 1.5 \\
Frequência (Hz) & 1.2 & 1 \\
\hline
\end{tabular}

\section{A.2 Neurônio artificial}

Para gerar o arquivo contendo a série de bursts do neurônio artificial, usamos os seguintes parâmetros :

- $T_{\min }$ : tempo mínimo para ocorrência do primeiro spike;

- $T_{m a x}$ : tempo máximo para ocorrência do último spike;

- $N_{\min }$ : número mínimo de spikes por burst;

- $N_{\max }$ : número máximo de spikes por burst;

- $T_{R}$ : tempo refratário mínimo.

Os parâmetros $T_{\min }$ e $T_{\max }$ são calculados em relação ao primeiro spike do ultimo burst do neurônio biológico (Figura 23). Estes parâmetros são ajustados de forma a garantir que neurônio artificial dispare apenas durante a fase hiperpolarizada do neurônio biológico. Os bursts são construídos sorteando-se aleatoriamente, dentro dos limites dados, o número 
de spikes por burst e suas posições dentro dos bursts. Desta forma, o neurônio biológico interfere apenas na posição (fase) do burst do neurônio artificial, não tendo nenhum efeito sobre os outros parâmetros como os padrões de IBSPs, por exemplo.

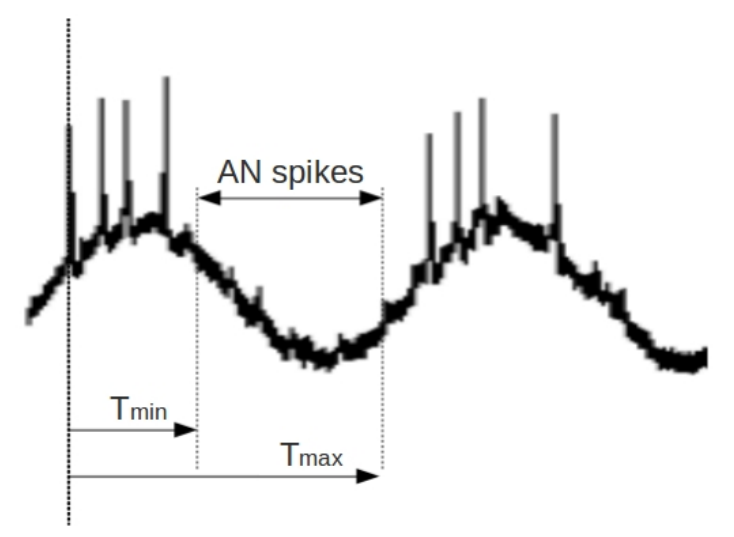

Figura 23 - Parâmetros do neurônio artificial. Definimos para cada experimento os limites da distribuição de spikes do neurônio artificial, de forma que este dispare em anti-fase com o neurônio biológico. Estes parâmetros são contados a partir do primeiro spike do último burst do neurônio biológico

Mostramos na figura 24 a distribuição do tempo de ocorrência dos spikes do AN em relação ao primeiro spike do burst de resposta. Observe que não há diferenças significativas nas distribuições para os ciclos normal e com condutância congelada. 

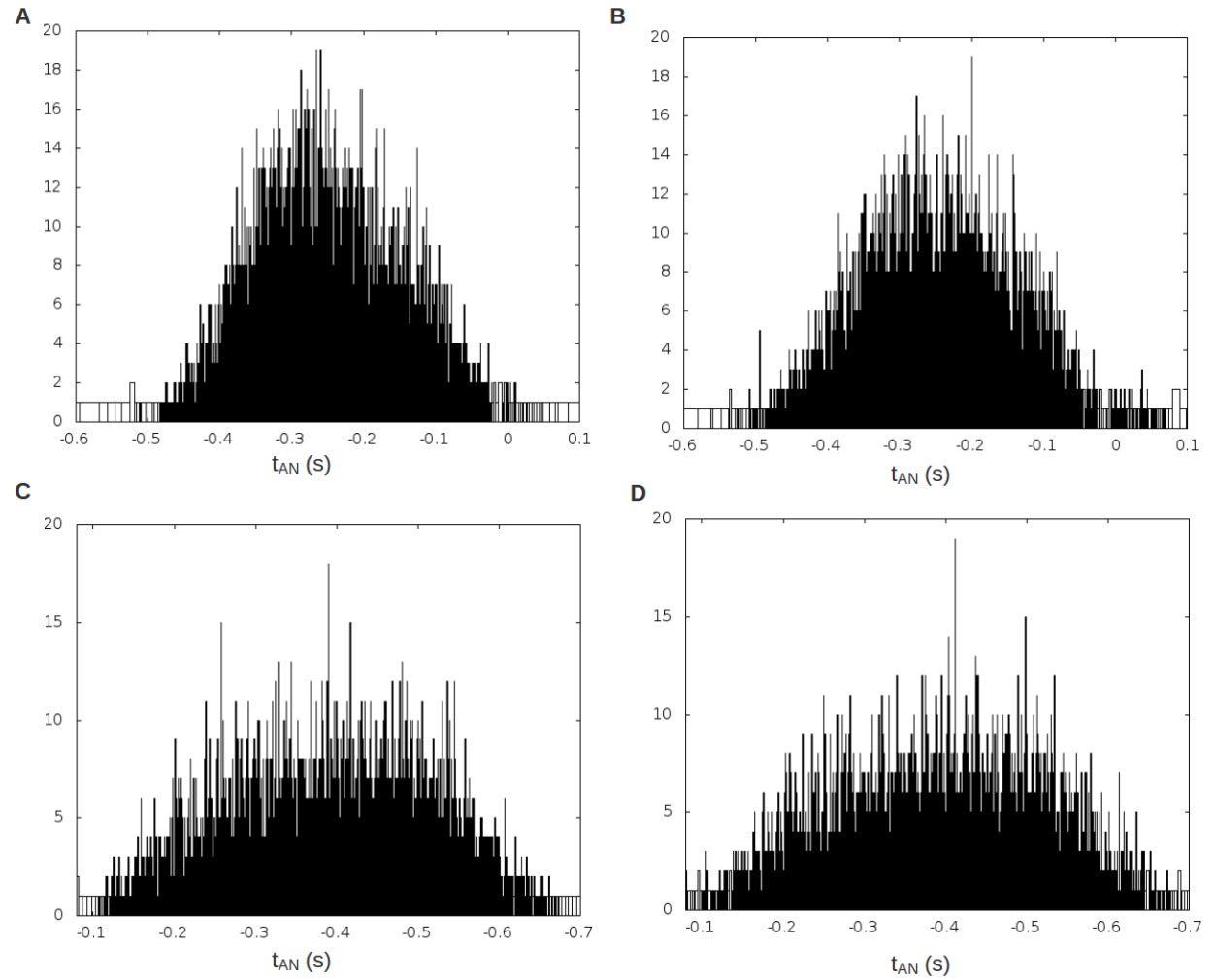

Figura 24 - Distribuição de spike do neurônio artificial. No eixo $x$ mostramos o tempo de ocorrência do potencial de ação e no eixo $y$ o número de disparos. Os tempos de disparo são calculados em relação ao primeiro spike do burst de resposta. A Exp. I, condutância dinâmica. B Exp. I, condutância congelada. C Experimento II, condutância dinâmica. D Experimento II, condutância congelada. Note que as distribuições não apresentam diferenças significativas entre os ciclos normal e com dinâmica congelada. 